Elok Mulyoutami, Pratiknyo Purnomosidhi, Asep Suryadi, Iskak Nugky, Nikolas Hanggawali, Gerhard Sabastian, Suci Anggrayani, James M Roshetko 



\section{Growing plants on a barren hill: local knowledge as part of land restoration in Sumba Timur, Indonesia}

Elok Mulyoutami, Pratiknyo Purnomosidhi, Asep Suryadi, Iskak Nugky, Nikolas Hanggawali, Gerhard Eli Sabastian, Suci Anggrayani, James M Roshetko

Working paper no. 290

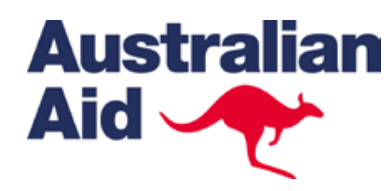




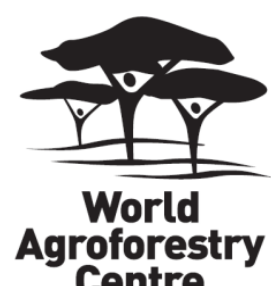

\section{Correct citation}

Mulyoutami E, Purnomosidhi P, Suryadi A, Nugky I, Hanggawali N, Sabastian G, Anggrayani S, Roshetko JM. 2018. Indonesia Rural Economic Development Series. Growing plants on a barren hill: local knowledge as part of land restoration in Sumba Timur, Indonesia. Working Paper 290. Bogor, Indonesia: World Agroforestry Centre (ICRAF) Southeast Asia Regional Program. DOI: http://dx.doi.org/10.5716/WP18030.PDF

Titles in the Working Paper series aim to disseminate interim results on agroforestry research and practices, and stimulate feedback from the scientific community. Other publication series from the World Agroforestry Centre include Technical Manuals, Occasional Papers and the Trees for Change Series.

Published by the World Agroforestry Centre

Southeast Asia Regional Program

JL. CIFOR, Situ Gede, Sindang Barang, Bogor 16680

PO Box 161, Bogor 16001, Indonesia

Tel: +62 2518625415

Fax: +62 2518625416

Email: icraf-indonesia@cgiar.org

ICRAF Southeast Asia website: http://www.worldagroforestry.org/region/southeast-asia/

(C) World Agroforestry Centre 2018

Working paper no. 290

Photos/illustrations: the authors

Disclaimer and copyright

The views expressed in this publication are those of the author(s) and not necessarily those of the World Agroforestry Centre. Articles appearing in this publication may be quoted or reproduced without charge, provided the source is acknowledged. All images remain the sole property of their source and may not be used for any purpose without written permission of the source.

This publication has been funded by the Australian Government through the Department of Foreign Affairs and Trade. The views expressed in this publication are the authors' alone and are not necessarily the views of the Australian Government. 


\section{About the authors}

Elok Mulyoutami joined ICRAF as a researcher in 2003. She graduated from the Universitas Padjadjaran Bandung, Indonesia with a major in Anthropology and a master of science in Rural Sociology from Institut Pertanian Bogor. She focuses on gender, local knowledge and migration issues.

Pratiknyo Purnomosidhi is an agroforestry researcher who has worked with ICRAF since 1993. His research interests include above- and belowground carbon deposits and agroforestry hydrology in Lampung and Jambi. He has been involved in various community empowerment activities focusing on agroforestry in Nanggroe Aceh Darussalam and Sulawesi. He obtained his Master Degree in Soil and Water Management Science from Gadjah Mada University, Yogyakarta and his Bachelor Degree in Soil Science from Brawijaya University, Malang.

Asep Suryadi has worked with ICRAF Indonesia since 2002 as a Farmer Specialist. He was involved in the Indonesia Rural Economic Development project in Sumba Timur. Asep is a facilitator and a technical resource for farmers' group training and agroforestry activities. He focuses on seedling systems and farmers' experimental plot development.

Iskak Nugky Ismawan is a farmer specialist who provides consultations on tree nursery development and agricultural method training for farmers. He was involved with the Indonesia Rural Economic Development project in Sumba Timur.

Nikolas Hanggawali joined ICRAF in 2016 as a Field Assistant for the Indonesia Rural Economic Development project. He assisted farmers in designing and managing silvicultural systems and experimental plots and in developing tree nurseries.

Gerhard Eli Sabastian is an agroforestry system researcher at ICRAF with 20 years of experience in research in developments in Indonesia. He was the Project Manager for ICRAF's component in the Indonesia Rural Economic Development project. His research has been mainly related to smallholders' agroforestry systems, focusing on the development of silvicultural management and non-timber forest products for local economic strengthening and sustainable environmental services. He obtained his doctorate in Forest Management from the Australian National University and his Master Degree in Natural Resources Management from Institut Pertanian Bogor.

Suci Anggrayani has worked as an agroforestry researcher at ICRAF since 2014. She has focused on data management and analysis of silviculture and smallholder agroforestry management in Gunung Kidul, Sumbawa, Timor Tengah Selatan and Sumba Timur districts. Her Bachelor Degree was obtained in 2014 from the Statistics Department, Faculty of Mathematics and Natural Science, Bogor Agriculture Institute.

James M. Roshetko is a researcher in agroforestry systems and leader of the Trees, Agroforestry Management and Markets Unit at ICRAF Southeast Asia. He has 27 years of experience, including 18 years in Indonesia. His current research focuses on tree-based, small-scale farming system as a sustainable farming and natural resource management system that contributes concretely to local economic development and also globally to environmental conservation. He holds a doctorate in Earth Science and Natural Resource Management from the University of Copenhagen, Denmark and he obtained his Master Degree in Forest Management and Agroforestry from Michigan State University, USA. 


\begin{abstract}
Implementation of land restoration needs to be adjusted to local conditions to be more efficient and effective. Local communities are the actors with the best understanding of the environment because they have been managing it for generations. For restoration to fit with local conditions, local knowledge of, and experience with, restoration and environmental functions need to be acknowledged. Communities' knowledge of the different types of soil and plants needs to be documented as a reference when selecting types of plants that have conservation value and are able to bring benefits to a community. The communities of Haharu Sub-district, Sumba Timur District, Nusa Tenggara Timur Province, Indonesia have developed their knowledge and farming practices based on their subsistence need for food. They have worked with limited land size, low precipitation, rocky ground and thin soil, deploying various semi-traditional conservation efforts developed by their ancestors, such as the 'timbak' system for productive land and 'ramang' for fallow. The introduction of intercropping was aimed at strengthening food security. Practices were adapted based on the new knowledge that they gained from interaction among community members and with people from outside their communities. Local knowledge could not be separated from the local belief system, known as 'marapu'. Communities' knowledge still needed to be strengthened in 1) pest and plant diseases and how to overcome them; 2) Production of good quality seeds and seedlings; 3) water management.
\end{abstract}

\title{
Keywords
}

Local knowledge, savanna, restoration, land management, agroforestry, Sumba, Indonesia, dryland 


\section{Acknowledgements}

This research was carried out as part of the Indonesia Rural Economic Development program initiated by Wahana Visi Indonesia with support from World Vision Australia and in cooperation with Lutheran World Relief. The program was funded by the Australian Government's Department of Foreign Affairs and Trade.

We express our sincere gratitude to our colleagues at Wahana Visi Indonesia who were our field companions in Haharu Sub-District. We also express our wholehearted gratitude to all community members who spent their time to work with us in identifying types of plants and discussing conditions in the sub-district. Moreover, we would also like to express our sincere gratitude to Phoebe P Agustin Pandyopranoto who help us on translating this manuscript, and Rob Finlayson for editing the English version. 


\section{Contents}

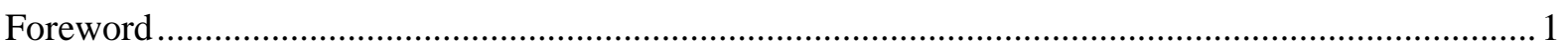

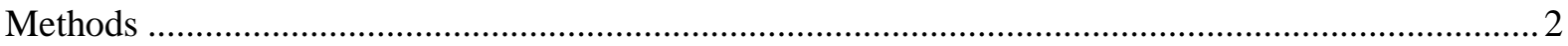

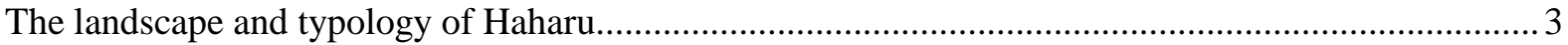

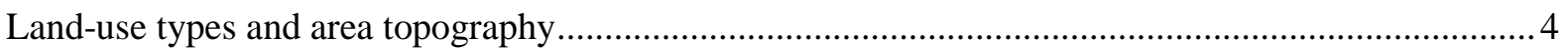

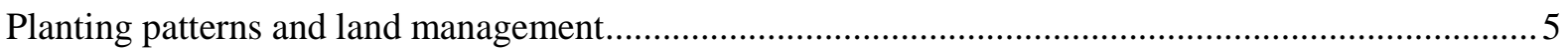

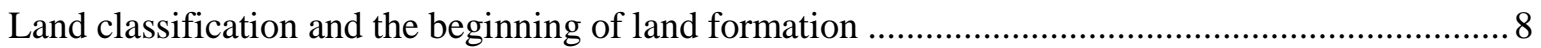

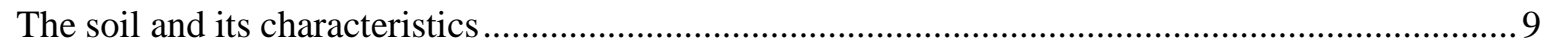

‘Timbak'/‘Lambang': land and water conservation for farming ...................................................... 10

The function of plants in food-crop land ....................................................................................... 11

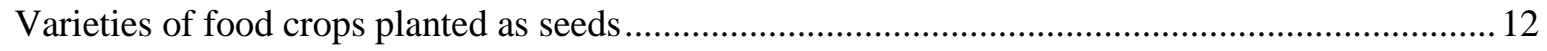

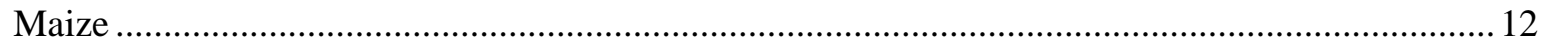

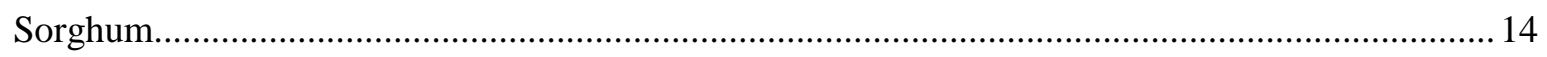

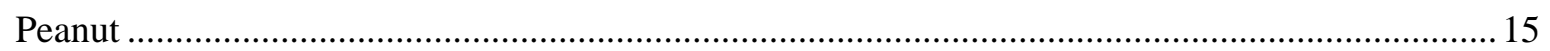

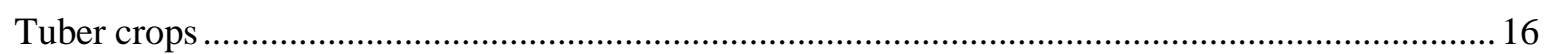

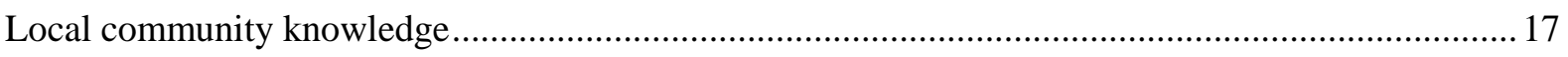

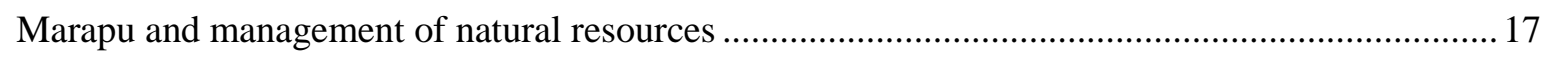

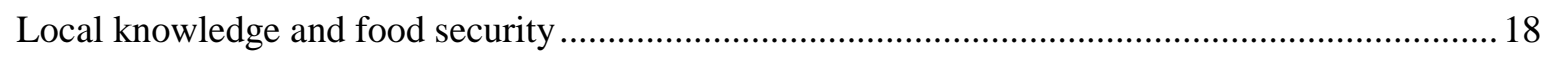

Knowledge production: local traditional and external................................................................. 18

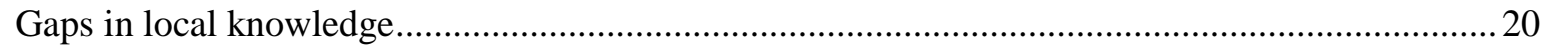

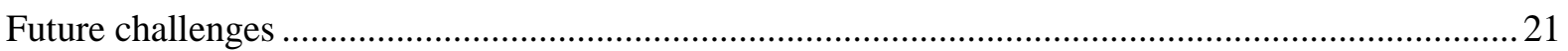

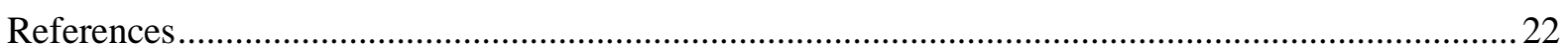

Attachment: List of plants and their locations identified with the communities ...............................25 


\section{Tables}

Table 1. Land typology, Haharu Sub-District, Sumba Timur District, Indonesia..................................

Table 2. Local understanding of land-use typology based on land location ......................................... 4

Table 3. Seasonal calendar and planting patterns based on land typology ........................................... 6

Table 4. Community knowledge of soil types and their characteristics ............................................. 10

Table 5. Maize types and their different characters …..................................................................... 13

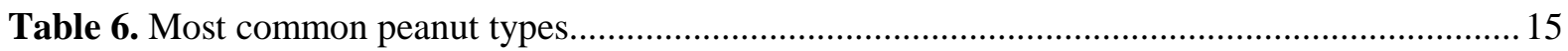

\section{Figures}

Figure 1. The study area in Haharu Sub-District, Sumba Timur District, Indonesia .............................2

Figure 2. Land-use typology based on land location ...................................................................... 4

Figure 3. 'Ramang': productive land that was not cultivated but left fallow for a time ........................ 8

Figure 4. Land classification based on tree density, age and previous land use ................................... 9

Figure 5. Timbak: land conservation using vegetative and semi-mechanical techniques....................11

Figure 6. The peanut farming land in Kalamba, with some trees such as 'lontar' (Borassus flabellifer)

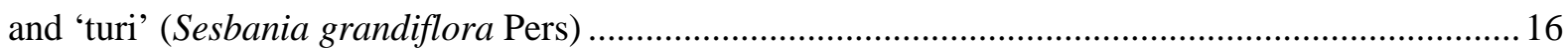

Figure 7. Farm land in the valley in Mbatapuhu, with different food crops planted in one location... 17 



\section{Foreword}

The majority of Sumba Timur District and almost all of Haharu Sub-District is covered by savanna, resulting in a low level of water debit (Rengganis 2017). The topography is undulating, with hilly areas and a flat coastal area, leading to difficulty in water access for some communities. These conditions have been exacerbated by a decrease in forest cover.

Formerly known as Sandalwood Island, the forest area on Sumba declined significantly during the 20th century and was almost entirely lost by the early 2000s. Sitompul et al (2004) indicated that by 2004, remaining forest cover was around $11 \%$ of the total size of the island, with other land cover in the form of open forest and savanna. Over-harvesting of valuable native trees — sandalwood (Santalum album), 'lobung' (Decaspermium sp), 'injuwatu' (Pleiogynium timorense) and 'kosambi' (Schleichera oleosa) - resulted in almost total degradation of most of the land area.

Specific causes have been 1) large-scale timber extraction; 2) repeated clearance and burning of savanna for attempted cultivation; 3) freely grazing livestock; and 4) unsustainable fuelwood harvesting. The almost complete absence of trees in the savannas, combined with limited rainfall, leads to annual water shortages and sub-optimal food production exacerbated by poor soil and watermanagement practices. Sulaiman and Webb (2015) classified Sumba as 'severely vulnerable to food and nutrition insecurity'.

To overcome the deteriorating environmental conditions in Haharu Sub-District, restoration of forest ecological functions is necessary. Any restoration program would need to adapt to local conditions to be more efficient and effective. Local communities are the actors with the best understanding of the environment because they have been managing it for generations (Pawluck et al 1992, Mulyoutami et al 2014). For restoration to fit with local conditions, local knowledge of, and experience with, restoration and environmental functions need to be acknowledged. Communities' knowledge of the different types of soils and plants needs to be documented as a reference when selecting types of plants that have conservation value and are able to bring benefits to a community.

There had been various efforts to restore environmental functions. Most were implemented along with economic development by selecting crops with high economic value that were able to improve community livelihoods. The selection of economic crops needs to consider local plant types with high conservation values that also produce traditional benefits for the community. Participatory plant or crop identification based on local knowledge should identify not only the plants but also the best restoration models that can bring multiple benefits. Any development program initiated by external people should consider local knowledge in order to be more suitable with local environmental conditions (Pawluck et al 1992, Mulyoutami et al 2004, Joshi et al 2004, Njurumana 2006).

Local knowledge is community-owned knowledge of an ecological system, all the different components within it and the relationships among components (Joshi et al 2008). This knowledge develops from a community's observation of the ecology, topography, society and culture in the place where they live. It's called 'local' because this knowledge is unique in its nature and frequently differs between groups (Njurumana 2006, Warren and Rajasekaran 1993). Although it’s called local, 
however, this knowledge has an evolutionary characteristic where non-traditional values are able to configure it, whether or not traditional values are included in the knowledge. Following Thrupp's (1989) admonition to not romanticize the local or traditional knowledge, this study aimed to document local knowledge about managing the environment to support restoration work that fits with local conditions. Community involvement in this study was essential.

\section{Methods}

The study was conducted in all villages in Haharu Sub-District, including those newly established as a result of a village division process in 2016. Data collection was conducted over two weeks in March 2017. Investigation and documentation adapted the 'knowledge-based system' approach that had been applied in various socio-ecological systems (Sinclair and Walker 1998). Local knowledge was collected in an interview process involving 28 informants, using in-depth interview techniques applied to both individuals and groups. Informant selection targeted those with the greatest knowledge, that is, 13 informants; the remainder of the informants were self-selected. In the group interviews, a triangulation process was conducted by involving some participants.

Local knowledge was arranged in a unitary statement that had one meaning (Walker et al 1995). The statements were input to the Agro-ecological Knowledge Toolkit. The toolkit was used to document the knowledge in a database for ease of access. Another benefit of the toolkit was its ability to present local knowledge in diagrams so that the knowledge plot could be easily understood. Using an 'utilitarian' base (Sinclair and Walker 1999), the local knowledge was combined with scientific knowledge to develop suitable technologies to be applied in the development of agriculture and agroforestry for land restoration, food security and livelihoods' improvement.

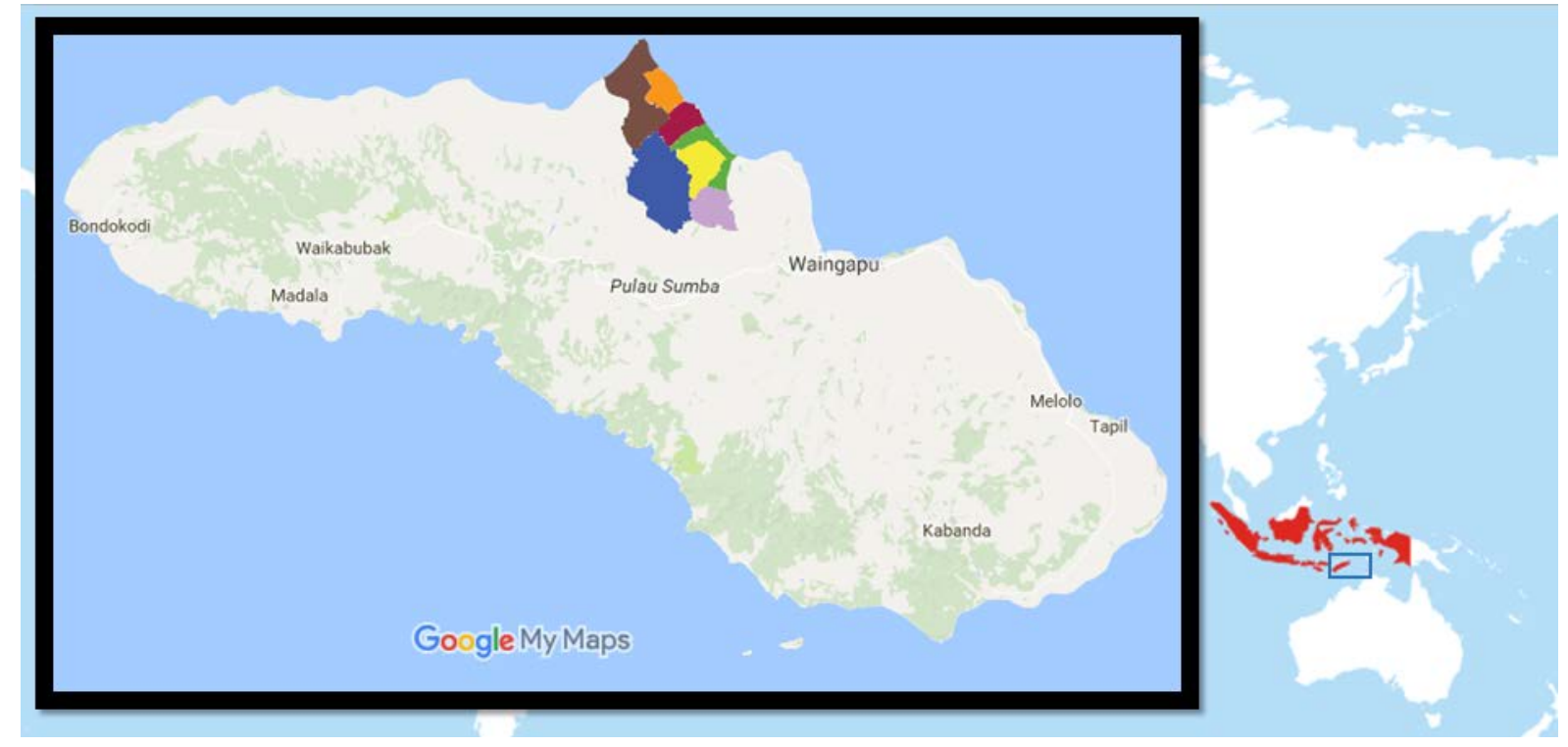

Figure 1. The study area in Haharu Sub-District, Sumba Timur District, Indonesia 


\section{The landscape and typology of Haharu}

The Haharu landscape features a coastal area and inland a large number of hills covered by savanna. Clusters of trees dominate narrow valleys in between the barren hills. Parts of the hills feature substantial areas of rocky outcrops that make it difficult for trees to take root and grow. Other parts of the hills are covered by a layer of white stones ('watu puda') or claystones that contain water. Taking into consideration the topography, physical characteristics of the rocks, soils and distance from villages to the coast, the Haharu Sub-District landscape was divided into three parts (Table 1). The table contain local definition of soil and stone characters based on community perception and equipped with technical term from geological maps by Effendi and Apandi (1994).

Table 1. Land typology, Haharu Sub-District, Sumba Timur District, Indonesia

\begin{tabular}{|c|c|c|c|c|c|}
\hline Landscape group & \multicolumn{2}{|c|}{$\begin{array}{l}\text { 1. Highland (DT/Dataran } \\
\text { Tinggi) }\end{array}$} & \multicolumn{2}{|c|}{$\begin{array}{l}\text { 2. Undulatory coastal with part of a } \\
\text { watershed (PIDAS - Pantai/Daerah } \\
\text { Aliran Sungai) }\end{array}$} & $\begin{array}{l}\text { 3. Undulatory } \\
\text { coastal (P - } \\
\text { Pantai/Coastal) }\end{array}$ \\
\hline Village name & $\begin{array}{l}\text { Mbatapuhu, } \\
\text { Prailangina, } \\
\text { Matawai } \\
\text { Pandangu }\end{array}$ & Kalamba & \multicolumn{2}{|c|}{ Rambangaru, Praibakul and Kadahang } & Napu and Wunga \\
\hline $\begin{array}{l}\text { Distance from } \\
\text { village centre to the } \\
\text { coast }\end{array}$ & \multicolumn{2}{|l|}{ Far } & \multicolumn{2}{|l|}{ Coastal } & Medium \\
\hline Topography & \multicolumn{2}{|l|}{ Highland, hills } & \multicolumn{2}{|c|}{ Undulatory coastal plain } & $\begin{array}{l}\text { Undulatory coastal } \\
\text { plain }\end{array}$ \\
\hline River & Not available & Available & \multicolumn{2}{|l|}{ Available } & Not available \\
\hline $\begin{array}{l}\text { Stone character } \\
\text { (community } \\
\text { perception) }\end{array}$ & \multicolumn{2}{|c|}{$\begin{array}{l}\text { White stones with deep } \\
\text { depth }\end{array}$} & \multicolumn{2}{|c|}{ Rocks (reefal limestone) } & $\begin{array}{l}\text { Rocks (reefal } \\
\text { limestone) }\end{array}$ \\
\hline \multirow[t]{2}{*}{$\begin{array}{l}\text { Geological map } \\
\text { (Effendi and } \\
\text { Apandi, 1994) }\end{array}$} & \multicolumn{2}{|c|}{$\begin{array}{l}\text { Kananggar Formation } \\
\text { ('Tmpk') }\end{array}$} & $\begin{array}{l}\text { Dominated by } \\
\text { Kaliangga } \\
\text { Formation } \\
\text { ('Qpk') }\end{array}$ & $\begin{array}{l}\text { Kananggar } \\
\text { Formation } \\
\text { ('Tmpk') }\end{array}$ & $\begin{array}{l}\text { Kaliangga } \\
\text { Formation } \\
\text { ('Qpk') }\end{array}$ \\
\hline & \multicolumn{2}{|c|}{$\begin{array}{l}\text { Marly sandstone, } \\
\text { tuffaceous sandstone, } \\
\text { tuffes, sandy marl, } \\
\text { limestone intercalation }\end{array}$} & \multicolumn{2}{|c|}{$\begin{array}{l}\text { Reefal limestone with 50-100 m depth } \\
\text { Marly sandstone, tuffaceous sandstone, } \\
\text { tuffes, napal sandy marl, limestone } \\
\text { intercalation }\end{array}$} & $\begin{array}{l}\text { Reefal limestone } \\
\text { with } 50-100 \mathrm{~m} \\
\text { depth }\end{array}$ \\
\hline Type of land use & \multicolumn{2}{|c|}{$\begin{array}{l}\text { 'Woka palindi'/'Woka uma' } \\
\text { 'Woka lola' } \\
\text { 'Mondu' }\end{array}$} & \multicolumn{2}{|c|}{$\begin{array}{l}\text { Woka palindi/woka uma } \\
\text { Mondu }\end{array}$} & $\begin{array}{l}\text { Woka palindi } \\
\text { Woka uma }\end{array}$ \\
\hline $\begin{array}{l}\text { Depth of water } \\
\text { source (community } \\
\text { perception) }\end{array}$ & \multicolumn{2}{|l|}{$50-100 \mathrm{~m}$} & \multicolumn{2}{|l|}{$10-50 \mathrm{~m}$} & $\begin{array}{l}\text { 10-50 m } \\
\text { 'Way kulup' } \\
\text { 'Mata wai' or } \\
\text { 'Lindi' }\end{array}$ \\
\hline Humidity & \multicolumn{2}{|l|}{ High } & \multicolumn{2}{|l|}{ Low } & Low \\
\hline
\end{tabular}




\section{Land-use types and area topography}

Mulyoutami et al (2016) described different types of land use in the Haharu landscape from the coast to the hills, including community settlements (Figure 2). The descriptions were based on local knowledge, in which the definitions were uniquely applied, that is, found only on Sumba. The local communities differentiated land types they managed based on the location of the land, whether the land was close to a water source, in a valley or on high land. The division of the land types is described in Figure 2 and Table 2 as presented by Mulyoutami et al (2016), with some added data and corrections.

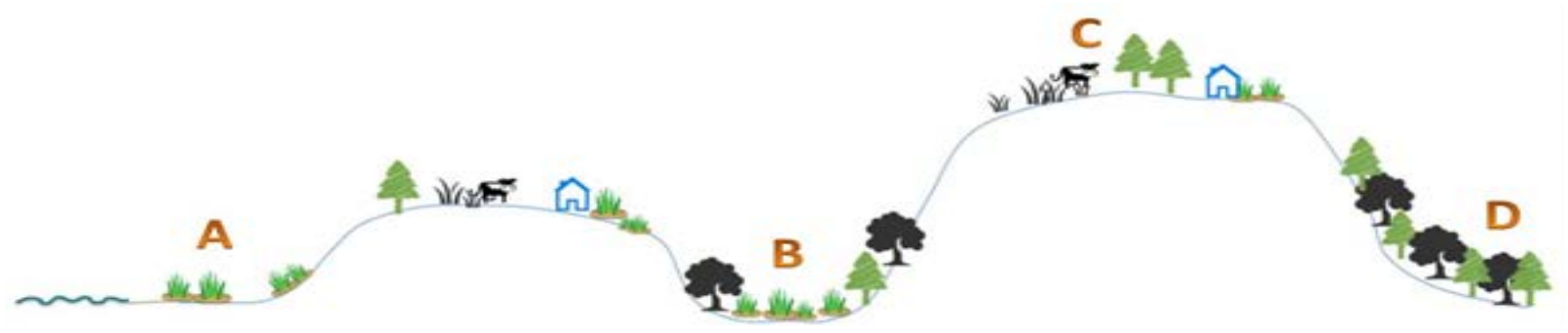

Figure 2. Land-use typology based on land location

Table 2. Local understanding of land-use typology based on land location

\begin{tabular}{|c|c|c|c|c|c|}
\hline Land use & $\begin{array}{l}\text { A. 'Mondu' } \\
\text { (watershed) }\end{array}$ & $\begin{array}{l}\text { 'Maradda' } \\
\text { (savanna) }\end{array}$ & $\begin{array}{l}\text { B. Woka lola } \\
\text { (farm land in } \\
\text { valleys) }\end{array}$ & $\begin{array}{l}\text { C. Woka (farm } \\
\text { land): woka } \\
\text { palindi, woka uma }\end{array}$ & $\begin{array}{l}\text { D. Forest area } \\
\text { ('utang'l'jamu' } \\
\text { ) }\end{array}$ \\
\hline $\begin{array}{l}\text { Vegetation } \\
\text { type }\end{array}$ & $\begin{array}{l}\text { Wetland rice, maize } \\
\text { ('kamborung'), } \\
\text { sweet potato, } \\
\text { tomato ('ambalai'), } \\
\text { chilli } \\
\text { ('mbakuhawu'), } \\
\text { bitter squash, } \\
\text { pumpkin ('kallah'), } \\
\text { fruit trees }\end{array}$ & $\begin{array}{l}\text { 'Kehi'/India } \\
\text { n ash tree } \\
\text { Grass } \\
\text { (Pennisetu } \\
\text { m spp). }\end{array}$ & $\begin{array}{l}\text { Dryland rice, } \\
\text { maize, sweet } \\
\text { potato, } \\
\text { sorghum } \\
\text { ('watar hamu') }\end{array}$ & $\begin{array}{l}\text { Maize } \\
\text { ('kamborung'), } \\
\text { cashew nut, } \\
\text { peanut ('manila'), } \\
\text { pigeon pea } \\
\text { ('kacang gude'), } \\
\text { coconut ('kokur') }\end{array}$ & $\begin{array}{l}\text { 'Kehi'/Indian } \\
\text { ash tree } \\
\text { Teakwood }\end{array}$ \\
\hline $\begin{array}{l}\text { Type of soil } \\
\text { (local } \\
\text { perception) }\end{array}$ & $\begin{array}{l}\text { Black soil } \\
\text { Sandy soil } \\
\text { Mixed soil }\end{array}$ & $\begin{array}{l}\text { Humus soil } \\
\text { ('hung') } \\
\text { Sandy soil }\end{array}$ & $\begin{array}{l}\text { Black soil } \\
\text { Grey soil }\end{array}$ & $\begin{array}{l}\text { Red soil } \\
\text { Black soil } \\
\text { White soil }\end{array}$ & $\begin{array}{l}\text { Fertile black } \\
\text { soil }\end{array}$ \\
\hline Gender role & $\begin{array}{l}\text { Male }(50 \%) \\
\text { Female }(50 \%)\end{array}$ & $\begin{array}{l}\text { Male } \\
(60 \%) \\
\text { Female } \\
(40 \%)\end{array}$ & $\begin{array}{l}\text { Male }(50 \%) \\
\text { Female }(50 \%)\end{array}$ & $\begin{array}{l}\text { Male }(40 \%) \\
\text { Female }(60 \%)\end{array}$ & $\begin{array}{l}\text { Male }(80 \%) \\
\text { Female }(20 \%)\end{array}$ \\
\hline $\begin{array}{l}\text { Water } \\
\text { source }\end{array}$ & A nearby river & $\begin{array}{l}\text { From } \\
\text { between } \\
\text { limestones }\end{array}$ & $\begin{array}{l}\text { Small spring } \\
\text { Rainwater } \\
\text { container }\end{array}$ & $\begin{array}{l}\text { Rainwater } \\
\text { container } \\
\text { Wells (a few) }\end{array}$ & $\begin{array}{l}\text { Small spring } \\
\text { Rainwater } \\
\text { container }\end{array}$ \\
\hline $\begin{array}{l}\text { Planting } \\
\text { time }\end{array}$ & $\begin{array}{l}\text { By the end of the } \\
\text { wet season (to } \\
\text { avoid floods) }\end{array}$ & - & $\begin{array}{l}\text { During the wet } \\
\text { season } \\
\text { (depending on } \\
\text { rainfall) }\end{array}$ & $\begin{array}{l}\text { During the wet } \\
\text { season but can be } \\
\text { planted throughout } \\
\text { the year }\end{array}$ & - \\
\hline
\end{tabular}




\begin{tabular}{|c|c|c|c|c|c|}
\hline Land use & $\begin{array}{l}\text { A. 'Mondu' } \\
\text { (watershed) }\end{array}$ & $\begin{array}{l}\text { 'Maradda' } \\
\text { (savanna) }\end{array}$ & $\begin{array}{l}\text { B. Woka lola } \\
\text { (farm land in } \\
\text { valleys) }\end{array}$ & $\begin{array}{l}\text { C. Woka (farm } \\
\text { land): woka } \\
\text { palindi, woka uma }\end{array}$ & $\begin{array}{l}\text { D. Forest area } \\
\text { ('utang'l'jamu' } \\
\text { ) }\end{array}$ \\
\hline $\begin{array}{l}\text { Land } \\
\text { ownership }\end{array}$ & $\begin{array}{l}\text { Community land; } \\
\text { people who are } \\
\text { able to manage the } \\
\text { land, usually people } \\
\text { with the same } \\
\text { family name or } \\
\text { he/she should have } \\
\text { special permission } \\
\text { from the } \\
\text { landowning family }\end{array}$ & $\begin{array}{l}\text { Family } \\
\text { land; it can } \\
\text { be used by } \\
\text { anyone } \\
\text { who lives in } \\
\text { the same } \\
\text { village } \\
\text { ('paraingu') }\end{array}$ & $\begin{array}{l}\text { In some areas } \\
\text { the land is } \\
\text { community } \\
\text { joint } \\
\text { ownership; in } \\
\text { others it is also } \\
\text { individually } \\
\text { owned }\end{array}$ & $\begin{array}{l}\text { Usually owned by } \\
\text { individuals }\end{array}$ & $\begin{array}{l}\text { Joint ownership } \\
\text { (sometimes } \\
\text { owned by } \\
\text { maramba/high } \\
\text { caste } \\
\text { members) }\end{array}$ \\
\hline
\end{tabular}

\section{Planting patterns and land management}

Most of the communities in Haharu Sub-District conducted seasonal farming. When the wet season began, they planted food crops. The communities put store in the prediction that the rains would start at the beginning of December, usually with a few days of low-intensity rainfall that increased in intensity for 4-5 months.

Rain increased the soil humidity required by plants to grow and to produce an adequate harvest. Based on the rainfall prediction, one-to-two months before the first rain the communities would prepare their farm land, hoeing and loosening the soil so that when the rain came the soil would be ready for planting. To prevent harvest failure, the communities usually waited for the rain to continue for several days, during which time they monitored soil humidity. When the soil was sufficiently humid, they planted. Palekahelu (2010) described a condition in which there was 'false' rain in 2008: it only rained for a few days. As a result, many farmers experienced harvest failure. Learning from that experience, the communities no longer planted immediately the first rain began but would first monitor the rain pattern before taking further action.

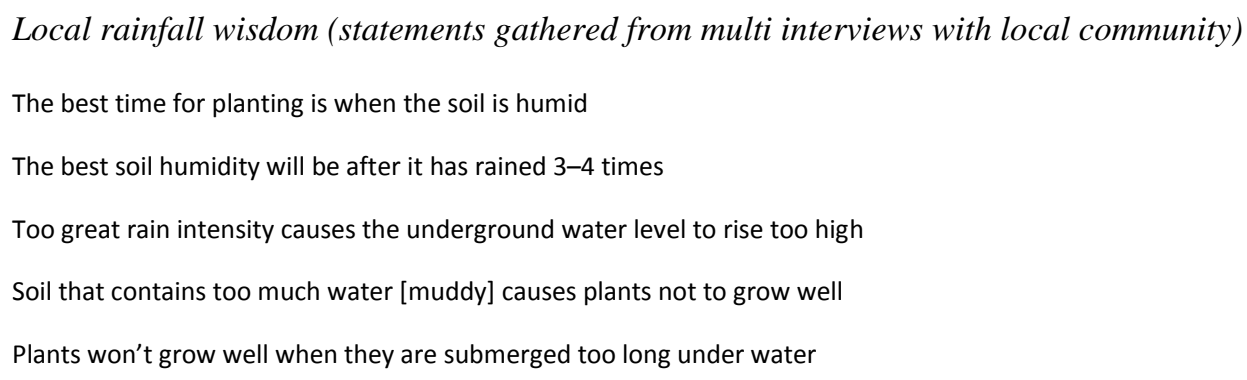

Referring to Table 1 and Figure 2, the practice of planting twice in a year mostly was done in the DT area where soil humidity was sufficiently high. In a small part of the highlands, Prailangina, the community was able to plant up to three times a year. In this area, maize (Sumbanese: 'kambaru' or 'kamborung') was planted in the first season (first two months) followed by 'jagung rote' (Indonesian; sorghum (Sorghum bicolor L)) that was usually diversified with sticky maize (Zea mays L. sinensis Kulesh). The second planting season extended for 3-4 months. In Kalamba (DT area) and in Praibakul (P-DAS area), in addition to maize the communities also planted peanut (Arachis hypogaea) in the first planting season. The annual planting pattern is illustrated in Table 3. 
Table 3. Seasonal calendar and planting patterns based on land typology

\begin{tabular}{|c|c|c|c|c|c|c|c|c|c|c|c|c|c|c|}
\hline & \multirow[b]{2}{*}{$\begin{array}{l}\text { Land } \\
\text { typology* }\end{array}$} & \multicolumn{12}{|c|}{ Month } & \multirow[b]{2}{*}{ Notes } \\
\hline & & 1 & 2 & 3 & 4 & 5 & 6 & 7 & 8 & 9 & 10 & 11 & 12 & \\
\hline Land preparation & $A, B, C$ & & & & & & & & & & & $\bullet$ & & \\
\hline Wet season & $A, B, C$ & - & $\bullet$ & $\bullet$ & & & & & & & & & • & \\
\hline Lola & A & & & & & & & & & & & & & \\
\hline $\begin{array}{l}2 \text { planting seasons } \\
\text { Maize }\end{array}$ & & - & $\bullet$ & & & & & & & & & & • & Planted in season 1 \\
\hline Sorghum and sticky maize & & & & $\bullet$ & - & $\bullet$ & $\bullet$ & & & & & & & Planted in season 2 \\
\hline Peanut & & $\bullet$ & $\bullet$ & $\bullet$ & $\bullet$ & $\bullet$ & & & & & & & $\bullet$ & Planted in season 1,2 \\
\hline $\begin{array}{l}1 \text { planting season } \\
\text { Maize }\end{array}$ & & • & - & & & & & & & & & & • & $\begin{array}{l}\text { Planted at the same } \\
\text { time; maize planted }\end{array}$ \\
\hline Sorghum & & - & • & $\bullet$ & & & & & & & & & & one week earlier \\
\hline ‘Iwi’ (bitter yam) & & - & $\bullet$ & & - & $\bullet$ & & & & & & & & $\begin{array}{l}\text { Planted in between } \\
\text { maize and sorghum }\end{array}$ \\
\hline Palindi & $\mathrm{A}, \mathrm{B}, \mathrm{C}$ & & & & & & & & & & & & & \\
\hline Maize & & - & $\bullet$ & & & & & & & & & & - & \\
\hline Sweet potato & & & & $\bullet$ & $\bullet$ & & & & & & & & & \\
\hline Cassava & & & & $\bullet$ & $\bullet$ & & & & & & & & & \\
\hline Mondu/watershed & $A, B$ & & & & & & & & & & & & & \\
\hline Maize & & - & • & • & & • & • & • & & • & - & - & & \\
\hline
\end{tabular}

The community had recognized that the high level of humidity in the DT (Table 1, Figure 2) area was caused by a thick underground layer of claystones. Claystone humidity caused the upper part of the soil layer to become humid. Despite the high humidity, the claystones did not retain water; available water was far below the claystones layer. Consequently, in the highland, water access was more difficult. To obtain water, wells had to be dug deeper than $20 \mathrm{~m}$, up to hundreds of metres.

Generally, the P-DAS and P communities, who usually farmed far from the river, only had one planting season, precisely when the first rains began. According to community knowledge, the soil in this area was not able to absorb water to maintain humidity. The dry soil was usually hard, reddish in colour with high infiltration ability so that it was not able to retain water. In this area, manure was needed to not only increase soil fertility but also because it had a high humidity level. Since the soil quickly became dry, after the first planting season ended nothing more was planted until the following year.

The type of stone in the P-DAS and P areas was reefal limestone or locally called as rock ('watu atur'). This type of reefal limestone did not absorb water, therefore, the soil on top of the rocks was dry. However, an underground water source was not too far from the surface, at 5-30 m. The challenge in accessing the water was mainly because of the thick layer of reefal limestone on the surface so it required a drilling measure. Water was able to be found in natural containers in the reefal limestone in the form of small ponds, called ‘way kulup' (Palekahelu 2010, Mulyoutami 2016). In P 
area, frequently the groundwater was affected by seawater intrusion and it was not able to be consumed.

Figures 2 and 4 show community experience of when and where agricultural activities could be undertaken in the valleys (lola) (B) and highlands (palindi) (C) surrounding their homes. Community perceptions were that the soil types and fertility levels of both lands were different. The soil in lola was black with humus content and more fertile compared to the soil in the palindi. The community reported that soil fertility in lola was gained from surface runoff from the palindi that concentrated in the lola during the wet season. The surface soil was quite fertile also because the community in this area frequently used manure in their agricultural practice.

Palindi land was dominated by reefal limestone and dry black soil with a thin layer of humus. To create a seasonal planting location surrounding their settlement, some of the community members applied fertilizer to soil placed on top of the limestone surrounding their homes or gardens. The soil was taken from a fertile location, such as from where trees grew, the banks of rivers or from fallow land. The community used manure to increase soil fertility by adding it on top of the soil up to a certain level of thickness (around 10-20 cm) so that it was able to grow short-rooted food crops.

The community who farmed next to the watershed (mondu) (A) were able to plant three times a year. Some community members who had land in the watershed had received a water pump to draw river water so that they were able to irrigate during water shortages. The pump operated around two times per week to draw the river water to higher land along a small canal so that the soil could absorb it. The community members who did not have access to a water pump planted 1-2 times per year and they watered the plants manually. On this land, the community also planted peanut and some vegetables in addition to maize.

Forest land was mostly located in deep valleys that made it impossible to access and be used as an agricultural plot. The boundaries of forest land were clear, further discouraging access. During the study, it was found that people usually accessed forests to look for 'iwi' ('sikapa' or 'gadung': forest or bitter yam (Dioscorea hispida Dennst), especially during periods of food insecurity.

There were different patterns of how the community planted food crops, described in Table 3. The community usually adjusted the planting pattern to the land size, labour availability, family food needs and preferences, such as whether the family preferred maize or sorghum. Other factors included plants required for religious rituals, for food diversification and in anticipation of harvest failure. The planting patterns described in this study were general patterns applied by the communities, however, there were wide variations, even in each separate community.

For those communities who applied two planting seasons, in the first they usually planted maize and in the second, sorghum, although some only planted maize in both planting seasons. In each maize and sorghum planting season, there were different varieties of each planted, including 'sticky' and coloured maize varieties, such as black, red and yellow. Some community members only planted peanut in both planting seasons, especially in the Praibakul area.

There were other communities who planted maize and sorghum at the same time during one planting season, following two planting patterns: 1) Maize was planted first, followed one month later by sorghum between the maize plants. After four months, the maize was harvested and the sorghum was 
allowed to grow taller. The communities' perceptions were that sorghum grew more quickly and had higher and lusher leaves compared to maize. Maize was harvested just before the sorghum leaves becoming lusher; and 2) Sorghum was planted along the sides of the plot and maize in the middle of the plot. The time difference between the sorghum and maize plantings was around 1-2 weeks. The communities planted maize earlier than sorghum, which would be harvested later than the maize. When the sorghum plants grew taller, they would not shade the maize.

\section{Land classification and the beginning of land formation}

The communities differentiated land types based on the history of land use. Part of the land was originally forest ('utang') and the other was originally savanna ('padang'). Whenever a community transformed savanna into land for cultivation, then the area would be called 'woka' or farm land. When a community transformed young forest or shrub land ('jamu') into farm land, it became known as 'kanguma'. The soil in kanguma, in general, was highly fertile.

Woka and kanguma referred to land that was used to produce food crops. However, after 3-4 harvests, the land would experience a decrease in yield. A fallow period was required to increase soil fertility.

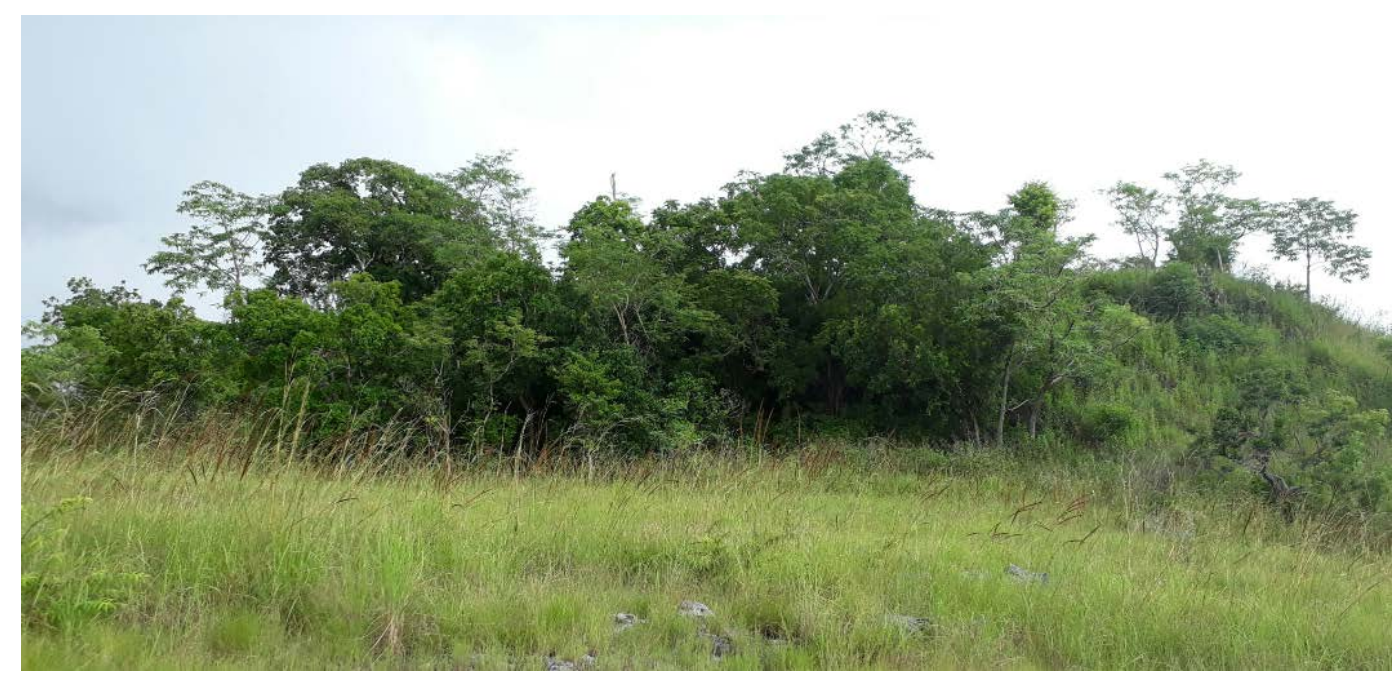

Figure 3. 'Ramang': productive land that was not cultivated but left fallow for a time

Woka and kanguma were short versions of the swidden or shifting cultivation that was applied by the communities in the past; land lay fallow, often for more than 20 years. Stimulated by an increasing population and decreasing availability of land, the fallow period was shortened to 3-6 years.

This shortened fallow period was also noted in Amarasi Village, Nusa Tenggara Timur Province, by some researchers. Agus et al (2007) explained that the Amarasi system with its shortened fallow period, used 'turi' trees (Sesbania grandiflora Pers) to restore soil fertility. The Amarasi communities also reaped economic value from the various types of trees they planted or which grew spontaneously.

In Haharu Sub-District, the shortened fallow system was called 'ramang' (Figure 3). Sesbania grandiflora was allowed to grow freely to restore fertility. Some non-governmental organizations and government agencies introduced plants to the communities and provided knowledge of plant types 
that grew fast and which could be direct planted or allowed to spontaneously grow to restore land functions, such as Calliandra.

Examining tree density, the communities classified forest into two: 1) utang (old forest); and 2) jamu (young forest). Utang was an extensive forested area with a high density of tall and large diameter trees and a substantial amount of other types of vegetation. In Haharu Sub-District, there were only a few areas that had utang, typically in deep and steep valleys that were difficult to access and convert to agricultural land. From a scientific perspective, the age of a forest can be determined by its tree size and density. Based on these indicators, utang was more than 60 years-old.

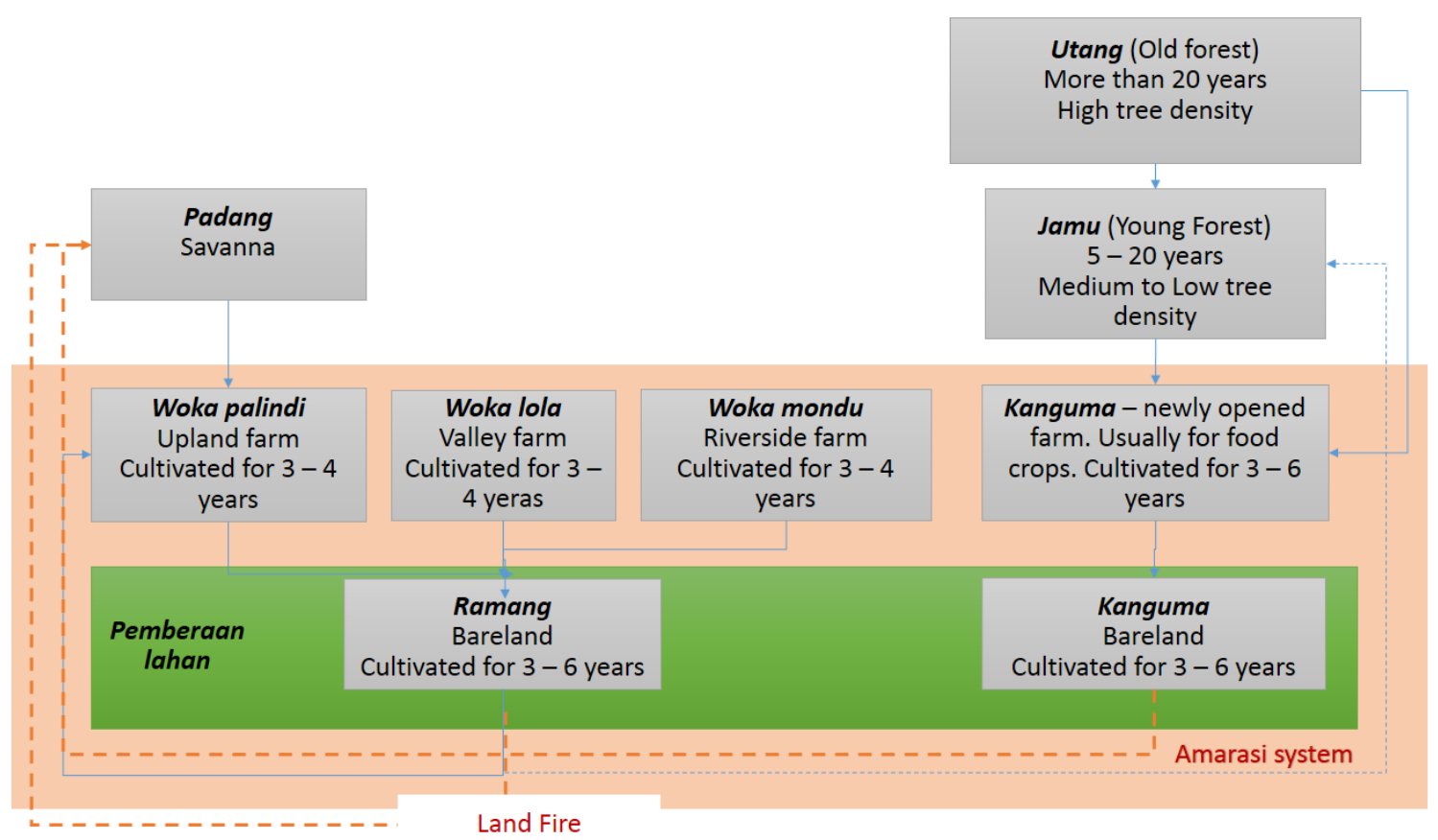

Figure 4. Land classification based on tree density, age and previous land use

Jamu was a small forested area with a low density of short and small diameter trees with a limited amount of other types of vegetation (around 10 types). Jamu were found mostly in valleys and near springs, occasionally in the highland or savanna. Systematically, the local understanding of forest classification and land use based on the previous land-use pattern is described in Figure 4.

\section{The soil and its characteristics}

The communities differentiated several types of soil in different areas in Haharu Sub-District. The communities' soil classification system was based on the physical characteristics of soil that were able to be seen and touched, that is, on colour and texture, as in many parts of the planet (Barrera-Bassols and Zinck 2003).

Communities' knowledge of the unseen processes that occurred in soil, such as the rise and fall of fertility and its relation to microorganisms and compost, lacked accuracy, as described by Wartenberg (2016) in a study of farmers' perceptions and land classification in neighbouring Sulawesi Island.

Some communities understood that there was a link between the dominant type of limestone found in 
an area and the soil condition in the same place. This knowledge was not only based on observable soil and limestone characteristics but also on the communities' abilities to understand their landscapes' conditions and connect them with the soil characteristics in an area. Ettema (1994) argued that this was soil classification based on a community's perceptual dimension. For example, referring to Table 1, black soil in the DT area was more fertile because it was in close proximity to claystones. The soil was moister because the claystones were able to retain water. Njurumana (2007) identified a system in Ramuk Village where it was possible to use the claystone soil for farming and to grow trees with long lifespans. Its condition was different from the black soil in the P-DAS and P areas, which was relatively dry because the type of underground limestone was reefal limestone that did not retain water. Njurumana (2007) indicated that sandy clay was able to reduce the surface runoff because it had a high infiltration capability. This knowledge then led the communities to decide whether to apply one or two planting seasons a year. Detailed descriptions of soil types recognized by the communities appear in Table 4.

Table 4. Community knowledge of soil types and their characteristics

\begin{tabular}{|c|c|c|c|c|c|c|c|}
\hline Type of soil & $\begin{array}{l}\text { 'Tana hung' } \\
\text { (humus soil) }\end{array}$ & Black soil & $\begin{array}{l}\text { Red-black } \\
\text { soil }\end{array}$ & $\begin{array}{l}\text { Silt soil } \\
\text { (Black soil } \\
\text { mixed with } \\
\text { silt) }\end{array}$ & $\begin{array}{l}\text { Sandy } \\
\text { black soil }\end{array}$ & $\begin{array}{l}\text { White } \\
\text { soil }\end{array}$ & Red soil \\
\hline Structure & Loose & $\begin{array}{l}\text { Rather } \\
\text { loose }\end{array}$ & $\begin{array}{l}\text { Hard and } \\
\text { sticky }\end{array}$ & $\begin{array}{l}\text { A little bit } \\
\text { harder }\end{array}$ & Loose & Hard & Sticky \\
\hline Particle content & Sand, loam & Loam & Clay & Silt & Sandy & - & Clay \\
\hline Water-holding capacity & Medium & High & High & Medium & Low & High & High \\
\hline Soil organic matter & High & High & Medium & High & Medium & Low & High \\
\hline Location & $\begin{array}{l}\text { Lola (valleys) } \\
\text { Palindi (few } \\
\text { only) }\end{array}$ & $\begin{array}{l}\text { Lola } \\
\text { (valleys) } \\
\text { Palindi }\end{array}$ & Palindi & Palindi & $\begin{array}{l}\text { Savanna } \\
\text { Palindi } \\
\text { Mondu }\end{array}$ & Savanna & Savanna \\
\hline
\end{tabular}

\section{'Timbak'/‘Lambang': land and water conservation for farming}

Some community members recognized the importance of conservation techniques on their land, especially in lola, on sloping land and river banks. A local conservation technique - terracing, known as 'timbak' - was applied extensively, especially, in most of the DT area and small parts of the P-DAS and P areas. Timbak originally referred to terracing to hold soil and prevent erosion. In practice, communities often combined timbak with bench terracing ('guludan'), to prevent the humus layer being carried away by water as surface runoff. For land in valleys, timbak was also useful for restraining material washed down from the highland so that it did not ruin the woka lola. In addition to ecological functions, timbak also served as a land boundary. Njurumana (2007) explained a traditional soil-and-water conservation model applied in Ramuk Village that was similar to timbak, known as 'palambang'.

The timbak can be built in three ways.

1) Mechanical $\rightarrow$ A terrace system where the vertical side of the terrace is reinforced by soil and stones placed on the terrace without cement. The aim is to enable water flow between the stones.

2) Vegetative $\rightarrow$ A terrace system where the horizontal side of the terrace is reinforced by plants that become a 'living fence'. The plant types planted for this purpose were white leadtree ('lamtoro', Leucaena leucocephala), calliandra ('kaliandra', Callyandra calotirsus), 'gamal' (Gliricidia sepium) and Indian ash tree ('kehi', Lannea coromandelica). 
3) Mechanical-vegetative $\rightarrow$ A terrace system where the sides of the terrace are reinforced by soil and stones and some plants or woods branches gained from 'palotang' planted on the terrace. Palotang is the trimming of trees that grow wild in the savanna, the aim being to accelerate the growth of the tree.
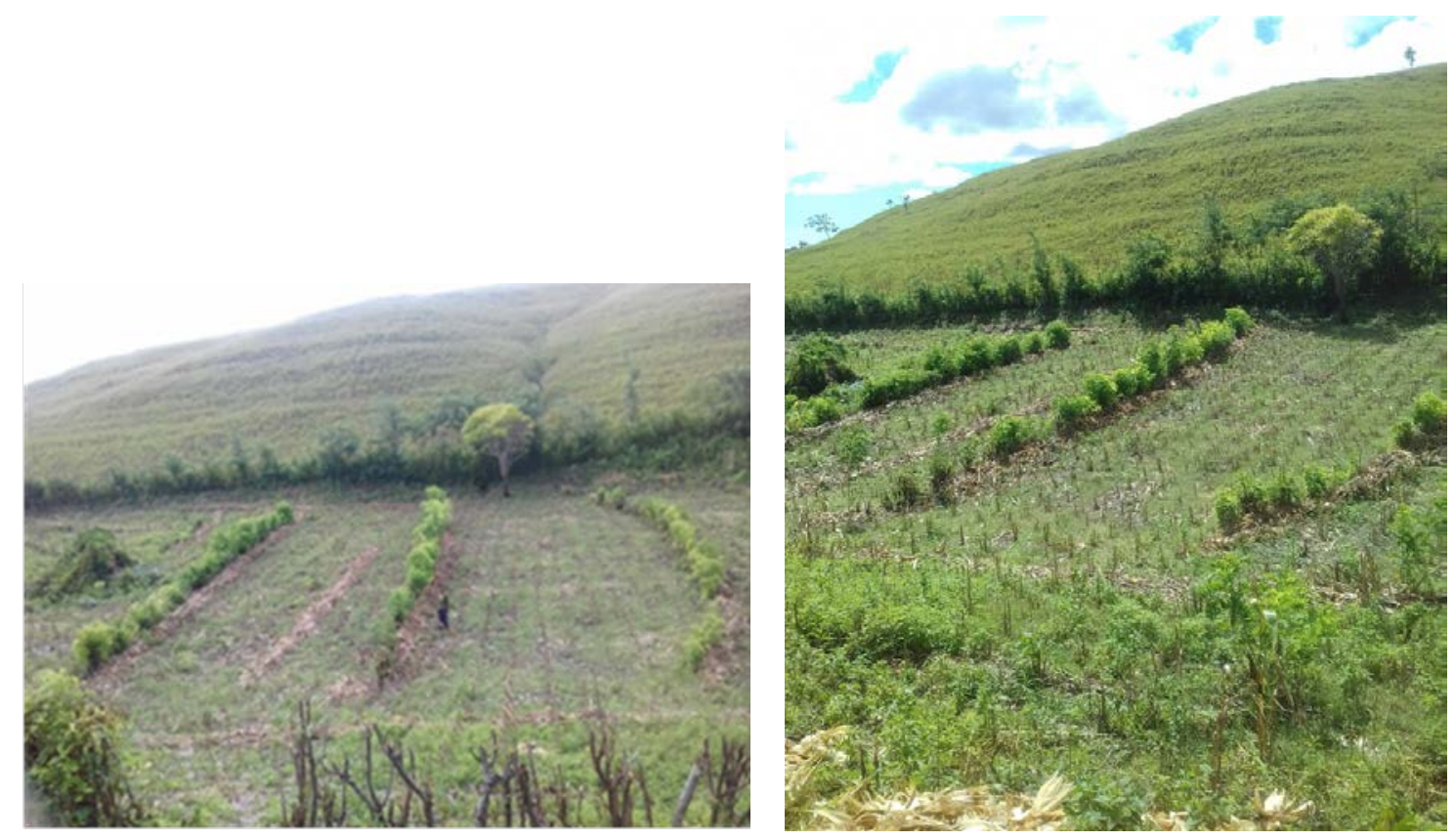

Figure 5. Timbak: land conservation using vegetative and semi-mechanical techniques

\section{The function of plants in food-crop land}

The communities well understood the relationship between tree types and soil fertility. Almost all of the community members interviewed during the study said that the trees growing on farm land were beneficial for soil fertility. The existence of certain tree types in the fields ensured that the communities no longer had to search elsewhere for leaves to cover the soil after harvests in order to restore soil fertility.

The tree types that grew freely on the communities' land were Sesbania grandiflora, Leucaena leucocephala and Gliricidia sepium. The community used the leaves to fertilize the soil. Sesbania was considered the most beneficial tree for the soil because the leaves, which were processed to become fertilizer or humus, were able to increase fertility. These trees had a deep and cold root type that was able to hold nitrogen. The soil where Sesbania grew had a relatively high fertility. Although parts of the Sesbania roots reached the surface, however, they did not spread too far. In Haharu, people were interested in planting Sesbania on their productive land and when they let it lie fallow the soil's fertility would recover in a relatively short period of time. Kieft (2007) noted that Sesbania, compared to Leucaena leucocephala, was also preferred by communities on the neighbouring island of Timor. Some of the farmers did not like Leucaena because it was considered invasive and competed with other plants on productive land. Further, this plant was quite vulnerable to attack by the psyllid pest. In 1985, an attack by Heteropsylla cubana killed most Leucaena on the island. Other members of the community considered that Leucaena were more fertile and could restore soil fertility with reduced fallow time between planting seasons (Djogo 1994, Yuksel et al 1999, Piggin 2003). As livestock 
feed, leucocephala had high nutritional value (Nulik 1998, Yuksel et al 1999, Hau and Nulik 2012). The introduction of Leucaena in Nusa Tenggara Timur began around 1930 in the Amarasi area (Djogo 1994), fully supported by the local government.

Gliricidia sepium was also considered to contribute to soil fertility and suitable for the soil condition. Just like Sesbania, Gliricidia had a deep-rooting system and was able to fertilize the soil. Gliricidia could become a 'living fence', however, there needed to be sufficient space between individual trees because its stem shape was not straight.

The Indian ash tree ('kehi', Lannea coromandelica) was prioritized for use as a fence. Its stem grew straight (when it was trimmed regularly) and was considered very suitable as a boundary fence. Additionally, this tree grew easily and was well adapted to all soil conditions in Sumba Timur. Lannea also fertilized the soil. Besides that, livestock liked this plant very much. Houses with Lannea fences were a local 'trademark', especially, in Haharu and, generally, in Sumba Timur. However, Lannea roots tended to emerge at the surface and cause damage. Further, Frans Wiila (head of the Forest Protection Unit, part of the Forestry and Plantation Agency in Sumba, personal communication) explained that Lannea consumed a lot of water, therefore, it was not suitable to be planted near springs. The communities stated that Lannea could not be planted next to food crops because of their rooting structure and high demand for water. Thus, Lannea required regular trimming. Trimming prevented the roots from spreading and encouraged the stems to grow straight and tall with a small diameter.

Some community members recognized that trees' functions on their farm land was not just as natural fertilizer, however, they were also able to cool the surrounding air. A large number of community members planted trees, or just let wild trees grow, on their farm land for shade. Typically, shade trees were those that were able to grow well and had small leaves ('gala-gala'), such as 'lontar' (Borassus flabellifer) and Sesbania.

\section{Varieties of food crops planted as seeds}

\section{Maize}

The Haharu communities prioritized farming patterns that were able to fulfill their subsistence needs, which because of the dry conditions were necessarily seasonal. Three types of crop planted frequently in Haharu were maize, sorghum and peanut (Mulyoutami et al 2016). Fowler (2005) said that maize and peanut became the very important subsistence livelihood sources for the people in Sumba since the mid-1500s. Moreover, Fowler (2005) indicated that maize is not only for their staple crop, but it has sacred symbol and used for the customary ceremony. Hundred years later till recently, maize and sorghum were planted to also fulfill their cash needs.

The Haharu community, as with the Sumba community in general, had seeds of various food crops that were very suitable for the environmental conditions and were easy to manage. Through development programs and other sources of external information shared with the communities, new types of food crops that were considered superior had been introduced. For the Sumba communities, maize was very important for religious ceremonies as well as for daily consumption, although Fowler (2005) and Martens (2013) noted that maize was an introduced plant. 
Sorghum was categorized as a 'more local' crop compared to maize. However, there was another earlier plant, called 'jelai', 'jali', 'hanjeli' or 'komangge' in Sumbanese and, in English, 'Job's tears', 'adlay' or 'adlay millet' (Coix lacryma-jobi L) (Fowler 2005). As well, the communities in Kambera and in some villages in Haharu were still familiar with 'kani' (Sumbanese), 'jewawut' (Indonesian) or 'foxtail millet' (Setaria italica). Both plants were once dominant. However, the length of their planting times, smaller productivity and difficult post-harvest management compared to rice and maize caused a decline in their popularity.

There were three maize categories that were usually planted by the local community. The first category embraced the various local seed types, including the regular, sticky and black, yellow and white coloured varieties. These local maizes had low productivity, however, their adaptation level to the soil was high, they were highly durable and could be stored for a long time. They were still frequently planted, especially by communities in the DT area (Mbatapuhu and Prailangina) because the varieties were more durable when they were stored traditionally, that is, in the 'karandi' system in which the plants were bundled together and tied in a tree.

The second category was open-pollinated maize, a superior type, which, unlike other superior types, could be reproduced in situ two or three times by the communities. This type was planted a lot in the P-DAS and P areas like Kadahang and Praibakul. Varieties included Bisma, Srikandi Kuning, Srikandi Putih and Lamuru varieties; the latter being used most. Lamuru was originally a superior type released by the Agriculture Research and Development Agency in cooperation with some companies around 2010 in the Nusa Tengarra Timur Maize Province Program (Vel and Nugrohowardhani 2012). The most important consideration was that the seeds were suitable to the local climate, particularly, the dry conditions in both Nusa Tenggara Barat and Nusa Tenggara Timur provinces.

The third category was hybrid maize. This was a new type of seed. It was not able to be reproduced like the open-pollinated types. Hybrid maize production was the highest, however, it had the lowest durability. Subagio and Aqil (2013) mapped the development of maize varieties in some areas in Nusa Tenggara Timur and found that the use of local seeds was still dominant in Sumba Timur, with only a few community members planting the open-pollinated type and even less planting the new hybrid type. Interviews conducted with the communities as part of this study found several maize types that were generally planted in Haharu Sub-District (Table 5).

Table 5. Maize types and their different characters

\begin{tabular}{|c|c|c|c|c|c|}
\hline $\begin{array}{l}\text { Comparison } \\
\text { attributes }\end{array}$ & $\begin{array}{l}\text { Red maize } \\
\text { (local) }\end{array}$ & $\begin{array}{l}\text { White maize } \\
\text { (local) }\end{array}$ & $\begin{array}{l}\text { Sticky maize } \\
\text { (local) }\end{array}$ & $\begin{array}{l}\text { Hybrid } \\
\text { maize }\end{array}$ & $\begin{array}{l}\text { Open-pollinated } \\
\text { maize (Lamuru) }\end{array}$ \\
\hline Planting time & 4 months & & & 3 months & $3-4$ months \\
\hline $\begin{array}{l}\text { Durability } \\
\text { against heat }\end{array}$ & Less durable & $\begin{array}{l}\text { Less } \\
\text { durable }\end{array}$ & Durable & Durable & Less durable \\
\hline Storage method & $\begin{array}{l}\text { Karandi } \\
\text { (hung) }\end{array}$ & $\begin{array}{l}\text { Karandi } \\
\text { (hung) }\end{array}$ & $\begin{array}{l}\text { Karandi } \\
\text { (wee hung) }\end{array}$ & $\begin{array}{l}\text { Inside a } \\
\text { sack }\end{array}$ & $\begin{array}{l}\text { Inside a sack } \\
\text { more often than } \\
\text { karandi }\end{array}$ \\
\hline Storage time & Long time & Long time & Long time & Not durable & Medium \\
\hline Density & Low & Low & Low & High & High \\
\hline Seed & Frequent & Frequent & Frequent & Cannot & Maximum 3 times \\
\hline
\end{tabular}




\begin{tabular}{|l|l|l|l|l|l|}
\hline $\begin{array}{l}\text { Comparison } \\
\text { attributes }\end{array}$ & $\begin{array}{l}\text { Red maize } \\
\text { (local) }\end{array}$ & $\begin{array}{l}\text { White maize } \\
\text { (local) }\end{array}$ & $\begin{array}{l}\text { Sticky maize } \\
\text { (local) }\end{array}$ & $\begin{array}{l}\text { Hybrid } \\
\text { maize }\end{array}$ & $\begin{array}{l}\text { Open-pollinated } \\
\text { maize (Lamuru) }\end{array}$ \\
\hline $\begin{array}{l}\text { reproduction } \\
\text { Suitability for } \\
\text { the land }\end{array}$ & High & High & High & Medium & High \\
\hline $\begin{array}{l}\text { Vulnerability to } \\
\text { disease }\end{array}$ & High & High & High & Low & Medium \\
\hline Fertilizer need & Low & Low & Low & High & Medium \\
\hline
\end{tabular}

Community members who planted two maize types reported that the open-pollinated maize was usually planted in the second planting season because it was considered more resistant to heat. The local maize usually was planted in the first planting season because it was considered to require high humidity and it was not resistant to heat.

The communities planted local maize in different ways. The most common was planting several types of local maize in one farming land. They planted each type of local maize in each different plot. At the time of this study, only three local maize types were usually planted. Mixing the maize varieties in one planting season was a strategy to prevent severe harvest failure. A similar strategy was also implemented by Dayak communities in Kalimantan who planted rice and by Papuan communities who planted sweet potatoes (Mulyoutami et al 2010).

\section{Sorghum}

The communities had usually planted local seeds of sorghum ('watar' in Sumbanese), which included black, white and red varieties. As for maize, in one planting season they planted various local varieties. The aim of planting local seeds was for food security and to conserve the seeds. Similar with sorghum farmers in Ghana (Kudadjie 2006), planting various local varieties aimed to observe the seeds that were able to survive environmental changes. White sorghum had been planted the most by Haharu communities. They preferred this sorghum type because of its taste and softer texture that allowed it to be processed more easily. The white sorghum variety was able to survive as the ecosystem gradually changed.

At the time of this study, however, sorghum was rarely planted because of the difficulty of processing. Nonetheless, Subagio and Aqil (2015) stated that communities only processed sorghum from time to time because it was considered a low-class food compared to maize and rice. Additionally, the limited amount of farm land led the community to prioritize maize for their staple food and peanut for sale.

The communities were of the opinion that taking care of sorghum was very easy. Sorghum didn't depend on rainfall; its water need was low compared to maize and peanut. Nevertheless, maize was still a priority because it was able to be managed intensively (Fowler 2005) and it was easier to process maize into food items compared to sorghum. Vel and Nugrohowardhani (2012) stated that sorghum planting was decreasing because its price was not as competitive as maize, furthermore, there was no government program that supported sorghum development. It was also said that sorghum was not pest resistant, especially when stored. 
Some community members planted both maize and sorghum. Aside from maize for ritual purposes, food diversification and anticipation of food failure were the factors that led the community to plant different types of crops. There were two planting patterns found: 1) Maize was planted first and then one month later sorghum was planted in between the maize. After 4 months, the maize was harvested and the sorghum was left to grow taller. The community members considered that sorghum had a faster growing time with higher and lusher leaves compared to maize. Maize was harvested just before the sorghum leaves were becoming lusher; and 2) Sorghum was planted on the sides of a plot and maize in the middle. The consideration was the harvest time for sorghum was later than maize so that when the sorghum grew higher it didn't hamper the maize.

\section{Peanut}

Sumba peanut was a high-quality local type famous for its unique taste. It was in high demand in the market. Haharu was the main peanut-producing area in Sumba Timur District.

Peanut production relied on sufficient rainfall because high humidity was needed to be optimally productive. The communities were familiar with two peanut types planted in Sumba: 1) 'kacang gali' (dug peanut) and 'kacang cabut' (pulled-out peanut). The peanut characteristics that the communities were familiar with are summarized in Table 6.

Table 6. Most common peanut types

\begin{tabular}{|l|l|l|}
\hline & Local peanut & Introduced peanut \\
\hline Planting distance & $20 \times 20 \mathrm{~cm}$ & $40 \times 40 \mathrm{~cm}$ \\
\hline Planting period & 4 months & 3 months \\
\hline Harvest method & By digging & By pulling out \\
\hline Taste & Good taste, sweet and smells good & Less sweet, neutral smell \\
\hline Production amount & On average, 1 pod has 3 beans. & On average, 1 pod has 2 beans. \\
\hline Harvest time and labour & The pod is dense and fills the skin. & The pod is small and not dense. \\
\hline Morphology & Low production level & High production level \\
\hline
\end{tabular}

Some farmers still applied traditional planting pattern to cultivate peanut. Peanut was planted as a monoculture or diversified (intercropped) with maize and sorghum. Iswanto et al (2015) stated that with the intercropping system, peanut should be planted 4-5 days after maize or sorghum. This system did not use planting beds. Three peanut beans were planted directly per hole, which was made with a stick, spaced $30 \times 40 \mathrm{~cm}$. The communities believed that the planting spacing would be able to increase the quality and quantity of the harvest. However, the Peanut and Tuber Plant Research Agency (Balai Penelitian Tanaman Aneka Kacang dan Umbi/Balikabi) recommended smaller planting spacings of $40 \times 20 \mathrm{~cm}$ or $40 \times 15 \mathrm{~cm}$ and use of fewer beans (usually only one). In general, the communities did not apply fertilizer although some community members used manure to increase production. The land was weeded one-to-two weeks after planting until the $60^{\text {th }}$ day. 
In Kalamba, the land was in a valley where some trees grew surrounding the community peanut land (Picture 6). Besides the harvests from the trees, they created shady places for the farmers and their leaves were a source of natural fertilizer.

After harvest, some community members left the peanut leaves on the land and let their livestock graze them. This was done with awareness that the leaves that were not consumed would become natural fertilizer along with livestock manure.

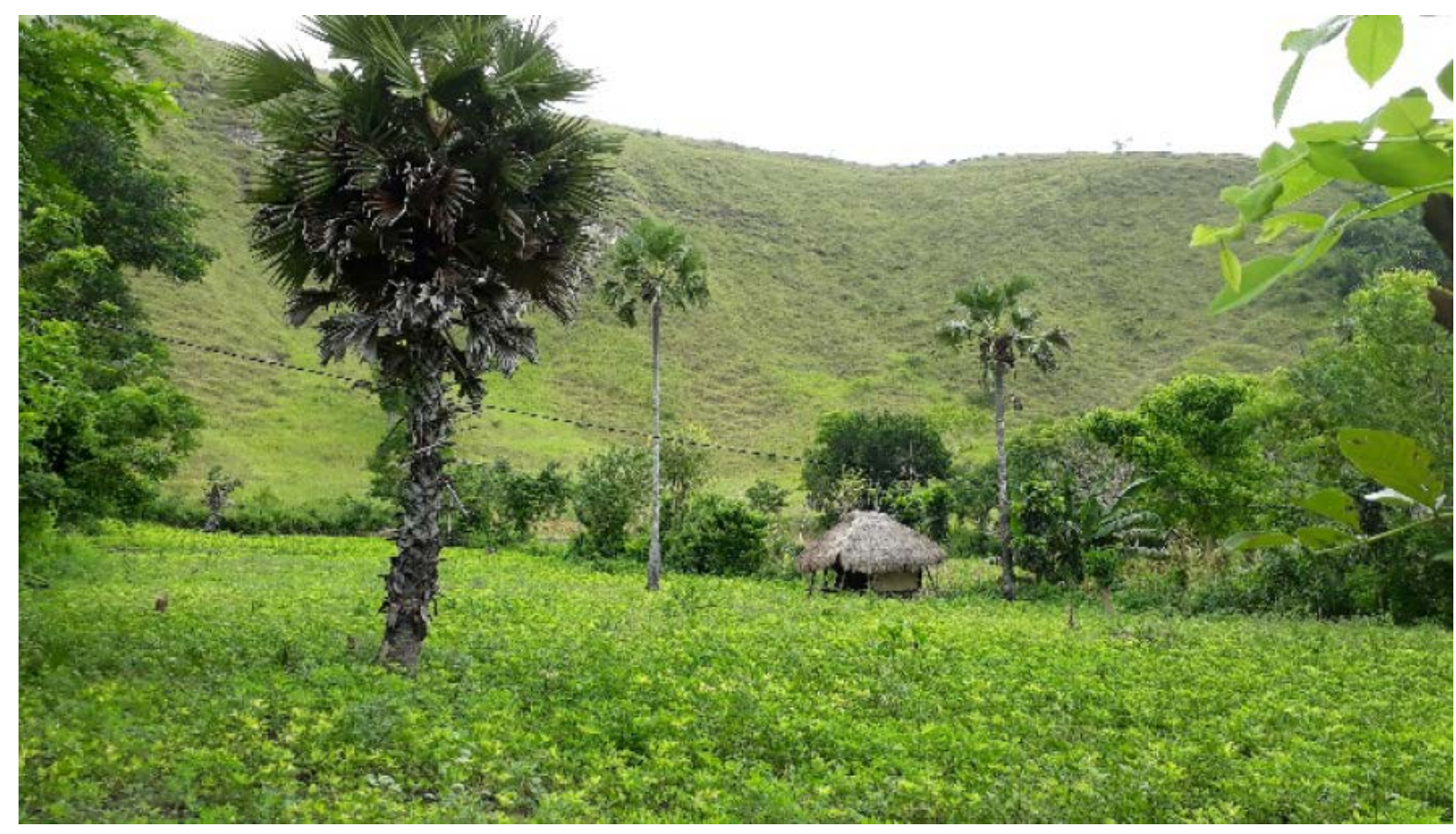

Figure 6. The peanut farming land in Kalamba, with some trees such as 'lontar' (Borassus flabellifer) and 'turi' (Sesbania grandiflora Pers)

\section{Tuber crops}

Tuber crops were an alternative food source for the communities. During a prolonged dry season, community members would enter the remnant forests to gather bitter yam (Dioscorea hispida Dennst) that grew wild or had been planted by their ancestors. Since bitter yam contained poison and was difficult to process, it was not the main food source for the community.

Some Haharu community members who inhabited the P-DAS location planted tuber crops in their gardens (woka uma), such as 'lutang', 'gembili' or lesser yam (Dioscorea esculenta), 'luwaye' or cassava (Manihot esculenta), 'katapu' or sweet potato (Ipomoea batatas), 'luwa' or coconut yam (Dioscorea alata). In Mbatapuhu, in the land located in the valley ('lola'), the farmers planted different types of yam, called 'luwa'. Luwa was planted beneath trees (usually Sesbania grandiflora Pers) that grew in between maize and peanut. The Sesbania were beneficial as they provided shade and natural fertilizer in the form of leaves. Various yam types that were planted included 'luwa hareu apeu', 'luwa mandu', 'luwa kambu', 'luwa kamelarara' and 'luwa enggal', which featured different colours of tuber, such as white, ivory and purple. Further research into the various food crops in Haharu would enrich community knowledge and support food security. 


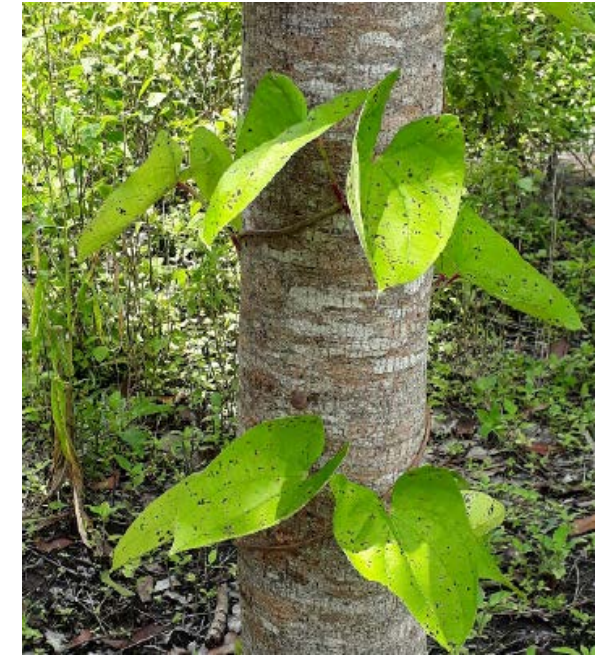

Figure 7. Farm land in the valley in Mbatapuhu, with different food crops planted in one location

Note: The Sesbania grandiflora Pers was used as a supporting structure for the Dioscorea alata

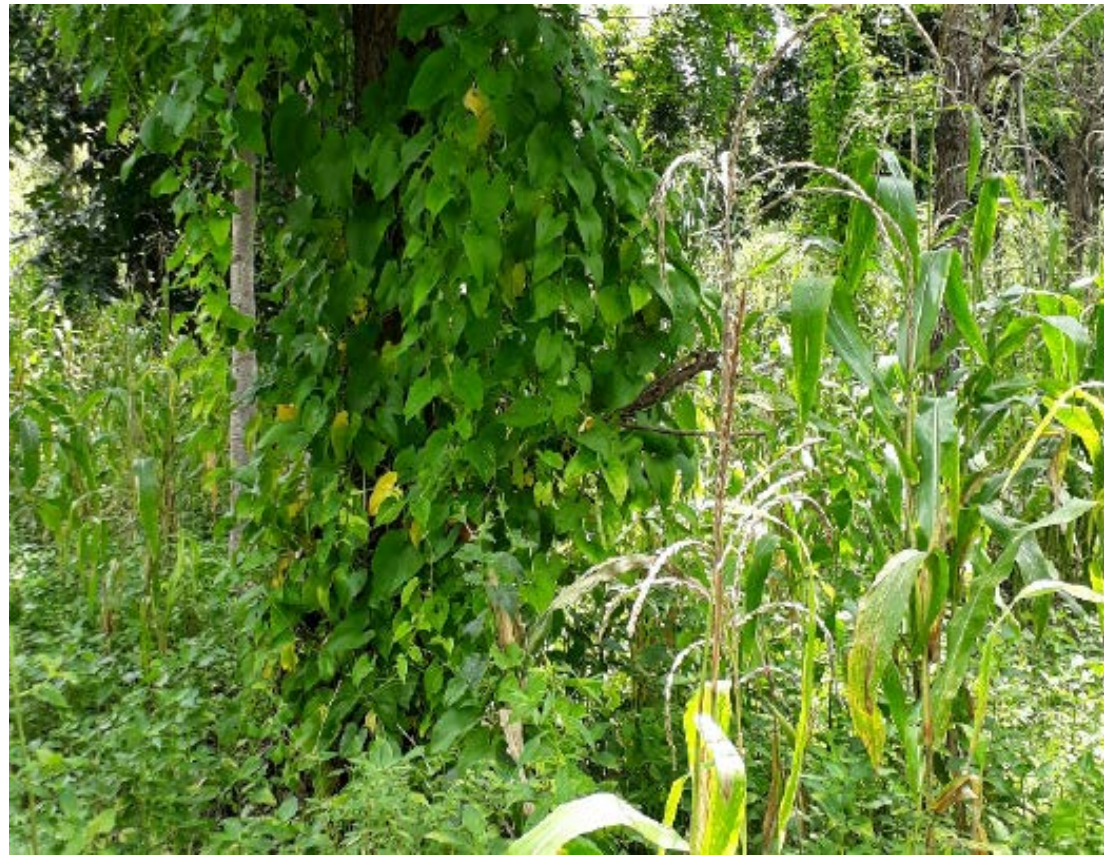

Dioscorea alata

\section{Local community knowledge}

The savanna was a blessing and at the same time also a distinct challenge for the Sumba Timur communities. The simplicity of the landscape produced a correspondingly simple knowledge system but it was enough to support community life. Orr et al (2012) argued that the Sumba Timur communities had their own views on trees, forests and deforestation that varied from community to community and landscape to landscape.

The challenge was how to manage land that was mostly limestones and grass with low precipitation. Agricultural activity was mostly to fulfill subsistence needs. When there was a harvest failure, tubers were gathered from the remnant forests to fulfil daily food needs.

In cultivating the land, the communities still practised semi-traditional conservation techniques that were established by their ancestors, such as 'timbak' for productive land and 'ramang' for fallow land (refer to Figure 4). Adjustments in field practice were made based on new knowledge gained during interaction both internally and also externally. Community knowledge could not be separated from the local marapu belief system.

\section{Marapu and management of natural resources}

Marapu was a local belief system that bound community members to their life centre, that is, their 'kampung' or 'paraingu' where their ancestors resided (Palekahelu 2010). Marapu formed individual and community identities and maintained bonds to nature and with another humans. The heart of marapu was the natural environment, causing adherents to care about human behaviour and its impact on the environment. Nature was the source of life and its sustainability needed to be managed. 
Three important components of marapu focused on the interrelation between the community and the natural environment, that is, how the community should 1) preserve the natural environment; 2) use natural resources efficiently; and 3) fairly, without over-exploitation.

Immanuel and Singgih (2010) described how community members gave meaning to nature and natural changes that were tightly related to marapu, forming the basis of local knowledge, along with social development, politics and the economy.

With the introduction of religions from outside of Sumba Timur, marapu began to fade. Vel and Makabombu (2010) and Fowler (2003) described how communities had begun to have less interest in implementing forest protection and conservation efforts for some plant types and increased interest in taking benefits from nature, correlating with a decrease in marapu ritual practices.

The natural phenomena that originally had been observed for guidance in managing the natural environment were not easy to recognize without marapu rituals. The rituals not only aided recognition but, critically, guidance in management. Ritual knowledge of the past could be blended with contemporary knowledge to create dynamic, informed management.

\section{Local knowledge and food security}

The communities developed their knowledge and local practices based on their subsistence needs, depending on their local conditions, the size of their farm land, low precipitation, rocky landscapes with thin layers of soil, and other factors that required specific skills and knowledge in naturalresource management.

In one area, intercropping maximized production and became the community's choice for fulfilling their subsistence needs. The lola management model in Mbatapuhu and other villages in the lowlands (DT) allowed different types of food crops to be planted together in a farm plot. The planting pattern took into consideration the crops' characteristics, the rainfall and soil conditions. Although the communities' knowledge was simple, it was proven to support their daily needs, creating a form of safety net. Nevertheless, efforts to maximize the farms’ productivity were still needed. Particularly because of the difficult farming conditions, improved, labour-efficient techniques were required for tuber crops, fertilizing and land clearing.

Post-harvest processing of all food crops also needed improved techniques. For example, bitter yam was a high-nutrition product, however, the fresh product was difficult to process. Therefore, the community only planted this crop during drought periods. Coconut yam was also a high-nutrition plant but was easy to cultivate (Trimanto and Hapsari 2015). Likewise, sorghum (Kudadjie 2006), Job's tears and foxtail millet were low in sugar and carbohydrate, recommending them for healthier diets. Martens (2013), however, stated that these plants had fewer harvests compared to rice or maize and both their planting and post-harvest processing periods were longer, therefore, they were less preferred. Improved processing technology should be developed before these local crops disappear.

\section{Knowledge production: local traditional and external}

Local knowledge in Sumba Timur was tightly related to the marapu belief system passed down from generation to generation. Some community members said that the practice of timbak, or terracing, that they applied was traditional knowledge from their ancestors. However, this practice had undergone 
changes since its initiation. In the past, only vegetative timbak was practised but by the time of this study mechanical timbak, and combinations of both practices, were applied. Similarly, with the selection of the type of plant to be used for timbak fencing, in the past, maize outgrowth leftover from the harvest was used but later a number of different types of plant were used. Presentation of knowledge from outside the villages, such as from non-governmental organizations working in Haharu, added to local communities’ traditional knowledge.

The entire Haharu community was quite open to receiving new knowledge and innovations. However, they did not necessarily directly apply new knowledge. The knowledge that was easily acceptable was that which corresponded most closely to local conditions and did not require high costs or much labour. For example, new knowledge about herbicides was not well applied. Although understanding that an herbicide was intended to easily rid the land of weeds, community members unfortunately applied it incorrectly, which caused the soil to become drier, leading to a decrease in yields. From this experience of applying the knowledge they had gained, community members also observed the results and tried to improve. We were able to see in this example how community knowledge developed over time. The communities' openness in accepting innovation and their willingness to learn were the keys to developing knowledge and technologies that could increase their farms’ productivity.

Participatory and adaptive approaches are required when external parties, such as agricultural extension officers and private-sector staff, wish to assist the communities increase their knowledge and skills. Successful examples should be established that can be replicated by other community members.

To conserve springs, the local community selected the native plants that grew around them. Local knowledge was that these plants were better at protecting the water source. Gliricidia sepium introduced by people external to Haharu was frequently planted in the sub-district, however, the communities did not see any benefit of the plant for water protection. The trees were used just to feed their livestock. At that time, the communities grew Gliricidia because the ready-to-plant saplings were provided by an external party. To collect saplings from the forest required more work yet the communities still maintained that forest trees held higher conservation value for the springs. The Gliricidia saplings were available and could be directly planted, therefore, the planting process was quicker.

This begs two questions: 1) Would the communities continue to plant when saplings were no longer provided by an external party? and 2) What was the survival rate of planted trees in land rehabilitation programs?

Propagation of saplings is a crucial part of any planting program implemented at community level. A community has to be able to do it themselves or be able to collect saplings from a forest to ensure that the planting would be successful. However, we observed that the Haharu communities' knowledge of propagation and maintenance was not sufficient for them to be able to make decisions about plantings, rather, decisions were more determined by practical needs.

Thus, in a community development and environmental restoration program, building of community capacity should be the core of a sustainable strategy. Such a strategy should seek to ensure that the community does not fall back on purely pragmatic decision making that does not bring sufficient impact in the long term. 


\section{Gaps in local knowledge}

Through observation and experience, the communities had learned how to manage their land and environment to fulfill their needs. They had classified land and soil types, confirmed by scientific knowledge, which helped the communities make decisions about how to manage their land. Soil classifications established by the communities focused on the soils' characteristics, similar to those used by other communities in other parts of the globe, that is, a soil's texture and colour (Ettema 1994). As presented by Weinstock (1984), the communities in Sumba Timur also had physical and perception dimensions as part of their classification of soils and land. For land, the physical dimension was the location's topography, the characteristics of the rocks, and the soil colour and texture.

The perception dimension was derived from experience in managing the land. Some community members through their perception were able to describe soil and land classifications at a landscape scale. However, their understanding was not adequate for observing the cause and effect relations among the concepts. The communities did not systematically formulate their knowledge, therefore, they needed intensive assistance. Documentation of local knowledge would assist with developing that knowledge. A participatory approach and direct practice in the field would help the communities increase their knowledge and build greater concrete understanding of the cause and effect relations among the components of their environment. The advisory approach of 'farmer to farmer' has been a proven effective strategy in developing community knowledge (Martini et al 2016). The approach does not only document knowledge but also shares knowledge between farmers, strengthening capacity (Martini et al 2016).

There were several gaps in local knowledge that needed to be filled.

1) Pests and diseases and how to overcome them

The communities were able to describe in detail the types of diseases that attacked their food crops, especially, maize and peanut. However, they did not know their names nor how to overcome. The agricultural extension officers sometimes were not able to provide a solution and, finally, the choice was to let the crops die.

\section{2) Quality seed and sapling production}

The selection of seeds, seedlings or saplings for planting on agricultural or barren land for conservation purposes was still limited to the types available in the remnant forests. Propagation involved planting saplings directly into the soil, with a resultant low success rate. Through a knowledge development and sharing process, the communities would learn how to dig suitable planting holes, apply fertilizer and water as necessary and measure survival rates. This would increase the success of any planting program. High-quality seedlings or saplings that were not available locally but had high conservation or economic value should also be cultivated using improved nursery techniques.

\section{3) Dependence on rainfall}

As a result of the dry climate, the range of plants available for selection was limited. The planting periods should also be adjusted to better fit with rainfall. A more comprehensive understanding needed to be developed of how the communities manage their land along with a corresponding implementation of efforts to ensure greater availability of water. 


\section{Future challenges}

Ramang and timbak are examples of land management combining ecological and economic functions. The systems not only provided a harvest for the people who cultivated the land but also served as environmental services providers, especially, related to increases in hydrological functions. Improving local knowledge of ramang, especially, regarding selection of plants that could provide both economic and environmental benefits, is needed to maximize benefits from the land.

Selection of alternative trees should consider suitability with the specific location, a factor that was well understood by the communities (Mulyoutami 2014, Njurumana 2008). In this matter, a combination of local and scientific knowledge is required to optimize land conservation efforts and to increase environmental and hydrological functions. The species selected as priorities by the Haharu communities, which could be fully integrated into the ramang and timbak systems, were Sesbania grandiflora Pers, Leucaena leucocephala, Gliricidia sepium and Lannea coromandelica.

To reduce dependence on rainfall, development of technology and knowledge needs to be implemented, as outlined below.

1) A landscape-wide perspective is required prior to implementation of rehabilitation measures to provide an effective and sustainable solution. Planting a combination of local and introduced trees surrounding springs could be applied, in close consultation with local communities.

2) At the plot level, rainwater needs to be contained for irrigation during droughts. Watercontainment principles, such as 'way kulup', can be adopted to optimize the use of available local material, for example, retention of water in limestone pools.

3) Plants should be selected that are most tolerant of local climate and environmental conditions Caution should be exercised in the use of local community knowledge, particularly, in the instance of parties who would like to use it for their own benefit rather than that of the communities of Haharu Sub-District and Sumba Timur District. Safeguards are needed to ensure that the communities reap the benefits of their local knowledge and that it is protected for their own use. Exploration of the application of intellectual property rights regarding local community knowledge should be undertaken. Mulyoutami et al (2009) highlighted the importance of establishing a reward mechanism for community knowledge that is not used for the community's interest.

This study was conducted through an interview process with key informants gained from a snowball sampling system. The method used in this study was not designed to understand the distribution of knowledge, the amount of knowledge nor what kinds of knowledge were recognized by the Haharu community as a whole. Further study is needed to understand the distribution of knowledge and whether such knowledge introduced to a community was fully distributed and adopted. 


\section{References}

Agus F. 2007. Use of Leucaena leucocephala to intensify indigenous fallow rotations in Sulawesi, Indonesia. In: Cairns M, ed. Voices from the forest: integrating indigenous knowledge into sustainable upland farming. Washington DC, USA: Resources for the Future. pp 287-294.

Barrera-Bassols N, Zinck JA. 2003. Ethnopedology: a worldwide view of the soil knowledge of local people. Geoderma 111(3):171-95.

Djogo AP. 1994. The use of forest tree legumes in Timor, Indonesia. In: Gutteridge RC, Shelton HM, eds. Forage tree legumes in tropical agriculture. Wallingford, UK: Centre for Agriculture and Bioscience International. pp 374-380.

Effendi AC, Apandi T. 1994. Peta geologi lembar Waikabubak dan Waingapu, Nusatenggara. Geological map of the Waikabubak and Waingapu sheets, Nusa Tenggara. Bandung, Indonesia: Pusat Penelitian dan Pengembangan Geologi.

Ettema CH. 1994. Indigenous soil classifications. What are their structure and function, and how do they compare with scientific soil classifications? Athens GA, USA: Institute of Ecology, University of Georgia. https://pdfs.semanticscholar.org/3c5e/f30b16fef967bf2bc1db98c22f3dba0e05b4.pdf

Fowler CT. 2003. The ecological implications of ancestral religion and reciprocal exchange in a sacred forest in Karendi (Sumba, Indonesia). Worldviews: Global Religions, Culture, and Ecology 7(3):303-29.

Fowler C. 2005. Why is Maize a Sacred Plant? Social History and Agrarian Change on Sumba. Journal of Ethnobiology 25(1), pp.39-57.

Hau DK, Nulik J. 2012. Potency of repromoting use of Leucaena in supporting cattle production and land conservation in East Nusa Tenggara. Proceedings of the International Conference on Livestock Production and Veterinary Technology. Bogor, Indonesia: Indonesian Center for Animal Research and Development. http://peternakan.litbang.pertanian.go.id/fullteks/semnas/pro-int12-45.pdf

Immanuel JM, Singgih PP. 2010. Marapu dalam bencana alam: pemaknaan dan respons masyarakat desa Wunga-Sumba Timur terhadap bencana alam. Marapu in natural disasters: the meaning and response of the people of East Wunga Village, Sumba to natural disasters. Thesis. Yogyakarta, Indonesia: Universitas Gadjah Mada.

Iswanto R, Noerwijati K, Dyah R, Anggraeni D A, Setyorini S D, Musaddad A. 2015. Laporan tahun 2015 hasil penelitian tanaman aneka kacang dan umbi. Report on various peanut and tuber research results 2015. Malang, Indonesia: Balai Penelitian Tanaman Aneka Kacang dan Umbi.

Joshi L, Wijaya K, Sirait M, Mulyoutami E. 2004. Indigenous systems and ecological knowledge among Dayak people in Kutai Barat, East Kalimantan: a preliminary report. ICRAF Southeast Asia Working Paper no. 2004_3. Bogor, Indonesia: World Agroforestry Centre (ICRAF) Southeast Asia Regional Program.

Joshi L, Manurung G, Akiefnawati RS, Mulyoutami E. 2008. Sistem sisipan: pengetahuan lokal dalan wanatani karet. Insetting system: local knowledge in rubber agroforestry. In: Adnan H, Tadjudin D, Yuliani EL, Komarudin H, Lopulalan D, Siagian YL, Munggoro DW, eds. Belajar dari Bungo: mengelola sumberdaya alam di era desentralisasi. Lessons from Bungo: managing natural resources in the era of decentralization. Bogor, Indonesia: Center for International Forestry Research.

Kieft JA. 2007. Farmers' use of Sesbania grandiflora to intensify swidden agriculture in North-Central Timor, Indonesia. In: Cairns M, ed. Voices from the forest: integrating indigenous knowledge into sustainable upland farming. Washington DC, USA: Resources for the Future. p 306.

Kudadjie CY. 2006. Integrating science with farmer knowledge: sorghum diversity management in north-east Ghana. Wageningen, Netherlands: Wageningen University and Research Centre. 
Martens MP. 2013. Grain crops in Indonesia. Sulang Language Data and Working Papers: Topics in Lexicography, no. 9. n.l. Sulawesi Language Alliance. http://sulang.org/sites/default/files/sulanglextopics009-v1.pdf

Martini E, Roshetko JM, Paramita E. 2016. Can farmer-to-farmer communication boost the dissemination of agroforestry innovations? A case study from Sulawesi, Indonesia. Agroforestry Systems 20:1-4.

Mulyoutami E, Stefanus E, Schalenbourg W, Rahayu S, Joshi L. 2004. Pengetahuan lokal petani dan inovasi ekologi dalam konservasi dan pengolahan tanah pada pertanian berbasis kopi di Sumberjaya, Lampung Barat. Local knowledge of farmers and ecological innovation in conservation and tillage in coffee-based agriculture in Sumberjaya, West Lampung. Agrivita 26(1):98-107.

Mulyoutami E, Rismawan R, Joshi L. 2009. Local knowledge and management of simpukng (forest gardens) among the Dayak people in East Kalimantan, Indonesia. Forest Ecology and Management 257(10):2054-61.

Mulyoutami E, van Noordwijk M, Sakuntaladewi N, Agus F. 2010. Perubahan pola perladangan: pergeseran persepsi mengenai para peladang di Indonesia. Changes in farming patterns: shifting perceptions of farmers in Indonesia. World Agroforestry Centre (ICRAF) Southeast Asia Regional Program.

Mulyoutami E, Tata HL, Janudianto. 2014. Local perceptions of land use systems and biodiversity in a rubber plantation of North Sumatra. Second International Conference of Indonesian Forestry Researchers, 27-28 August 2013, Bogor, Indonesia: Forestry Research and Development Agency, Ministry of Environment and Forestry. http://regions/southeast_asia/publicationsdo=view_pub_detail\&pub_no=PP0349-14-10

Mulyoutami E, Sabastian G, Roshetko JM .2016. Gendered knowledge and perception in managing grassland areas in East Sumba, Indonesia. Working paper no. 244. Bogor, Indonesia: World Agroforestry Centre (ICRAF) Southeast Asia Regional Program. http://dx.doi.org/10.5716/WP16160.PDF

Njurumana G. 2006. Nilai penting kearifan lokal dalam rehabilitasi lahan. The important value of local wisdom in land rehabilitation. Majalah Kehutanan Indonesia Edisi VI.

Njurumana GN. 2007. Konservasi tanah dan air berbasis masyarakat di Nusa Tenggara Timur: studi kasus di Desa Ramuk, Kabupaten Sumba Timur. Community-based soil and water conservation in East Nusa Tenggara: a case study in Ramuk Village, East Sumba District. Jurnal Penelitian Hutan dan Konservasi Alam 4(1):1-5.

Njurumana GN. 2008. Rehabilitasi lahan kritis berbasis agrosylvopastur di Timor dan Sumba, Nusa Tenggara Timur. Rehabilitation of critical land based on agrosylvopasture in Timor and Sumba, East Nusa Tenggara. Info Hutan 5(2):99-112.

Nulik J. 1998. The use of Leucaena leucocephala in farming systems in Nusa Tenggara, eastern Indonesia. Proceedings of the Third Regional Meeting of the Forages for Smallholders Project, Samarinda, East Kalimantan, Indonesia, 23-26 March 1998. CIAT Working Document No. 188. Vientiane, Lao PDR: Centro Internacional de Agricultura Tropical. http://ciat-library.ciat.cgiar.org/articulos_ciat/use_leucaena_178.pdf

Orr Y, Schimmer R, Geerken R, Castro A, Taylor D, Brokensha D. 2012. Ethno-ecology in the shadow of rain and the light of experience: local perceptions of drought and climate change in East Sumba, Indonesia. Climate Change and Threatened Communities 2012:175-84.

Palekahelu DT. 2010. Marapu: kekuatan di balik kekeringan potret masyarakat Wunga Kabupaten Sumba Timur Propinsi NTT. Marapu: the power behind the portrait of the Wunga people in East Sumba District, NTT Province. Thesis. Salatiga, Indonesia: Universitas Kristen Saya Wacana.

Pawluck RR, Sandor JA, Tabor JA. 1992. The role of indigenous soil knowledge in agricultural development. Journal of Soil and Water Conservation 47(4):298-302.

Piggin C. 2003. The role of Leucaena in swidden cropping and livestock production in Nusa Tenggara Timur Province, Indonesia. In: Da Costa H, Piggin C, Da Cruz CJ, Fox J, eds. Agriculture: new directions for a new nation East Timor (Timor-Leste). ACIAR Proceedings no. 113. Canberra, Australia: Australian Centre for International Agricultural Research. pp 115-129.

Rengganis H. 2017. Zonasi wilayah pendagunaan sumber daya air untuk pembangunan irigasi di Pulau Sumba, Nusa Tenggara Timur. Zoning of the area of water resources utilization for irrigation development in Sumba Island, East Nusa Tenggara. Analisis Kebijakan Pertanian 14(1):17-33. 
Sinclair FL, Walker DH. 1998. Acquiring qualitative knowledge about complex agroecosystems. Part 1: Representation of natural language. Agricultural Systems 56(3):341-63.

Sinclair FL, Walker DH. 1999. A utilitarian approach to the incorporation of local knowledge in agroforestry research and extension. In: Buck LE, Lassoie JP, Fernandes ECM, eds. Agroforestry in Sustainable Agricultural Systems. Boca Raton FL, USA: CRC Press. pp 245-276.

Sitompul AF, Kinnaird MF, O’Brien TG. 2004. Size matters: the effects of forest fragmentation and resource availability on the endemic Sumba Hornbill Aceros everetti. Bird Conservation International 14(S1):S2337.

Subagio H, Aqil M. 2013. Pemetaan pengembangan verietas unggul jagung di lahan kering iklim kering. Mapping of superior corn flour development in dry climates. Seminar Nasional Serealia. Maros, South Sulawesi: Balai Penelitian Tanaman Serealia. pp 11-19. http://balitsereal.litbang.pertanian.go.id/wpcontent/uploads/2016/12/2mu13.pdf

Subagio H, Aqil M. 2015. Perakitan dan pengembangan varietas unggul sorgum untuk pangan, pakan, dan bioenergi. Assembling and developing superior varieties of sorghum for food, feed and bioenergy. Iptek Tanaman Pangan 9(1). http://ejurnal.litbang.pertanian.go.id/index.php/ippan/article/view/2545

Sulaiman AA, Webb A. 2015. Food security and vulnerability atlas of Indonesia 2015. Jakarta, Indonesia: Ministry of Agriculture; Rome, Italy: World Food Programme.

Thrupp LA. Legitimizing local knowledge: "scientized packages" or empowerment for third world people. http://agris.fao.org/agris-search/search.do?recordID=US9037458

Trimanto T, Hapsari L. 2015. Diversity and utilization of Dioscorea spp. tuber as an alternative food source in Nganjuk Regency, East Java. Agrivita 37(2):97.

Vel JAC, Makambombu S. 2010. Access to agrarian justice in Sumba, Eastern Indonesia. Law, Social Justice, and Global Development Journal 1:15.

Vel JAC, Nugrohowardhani R. 2012. Plants for power: the potential for cultivating crops as feedstock for energy production in Sumba. The Hague: Humanistisch Instituut voor Ontwikkelingssamenwerking.

Warren DM, Rajasekaran B. 1993. Putting local knowledge to good use. International Agricultural Development 13(4):8-10.

Walker DH, Sinclair FL, Kendon G. 1995. A knowledge-based systems approach to agroforestry research and extension. AI Applications 9(3):61-72.

Wartenberg AC, Blaser WJ, Janudianto, Roshetko JM, Van Noordwijk M, Six J. 2016. Farmer perceptions of plant-soil interactions can affect adoption of sustainable management practices in cocoa agroforests: a case study from Southeast Sulawesi. Ecology and Society 23(1):18. https://doi.org/10.5751/ES-09921-230118

Weinstock J. 1984. Getting the right feel for soil: traditional methods of crop management. The Ecologist 14, 146-149

Yuksel N, Aoetpah A, Imo. 1999. The amarasi model: an example of indigenous natural resource management in Timor, Indonesia. Occasional Paper 1999/1. Indigenous Fallow Management Network. Bogor, Indonesia: International Centre for Research in Agroforestry.

Zulfikar A, Bahar N, Latif NA, Sukmawardany R, Sutisna T. 2001. Penyelidikan pendahuluan bahan galian industri di daerah Waingapu, Kabupaten Sumba Timur, Provinsi Nusa Tenggara Timur. Preliminary investigation of industrial excavation material in Waingapu, East Sumba District, East Nusa Tenggara Province. n.l. Sub Direktorat Mineral Non Logam, DIM. http://psdg.bgl.esdm.go.id/kolokium\%202001/7.\%20Waingapu\%20(Zulfikar).pdf 


\section{Attachment: List of plants and their locations identified with the communities}

\section{Food crops}

\begin{tabular}{|c|c|c|c|c|c|c|c|c|c|c|c|}
\hline Local name & Popular & Latin & Function & $\begin{array}{l}\text { Farm land } \\
\text { in valley } \\
\text { (woka lola) }\end{array}$ & $\begin{array}{l}\text { Farm land on } \\
\text { highland } \\
\text { (woka } \\
\text { palindi) }\end{array}$ & $\begin{array}{l}\text { Forest } \\
\text { (utang) }\end{array}$ & $\begin{array}{l}\text { Unused } \\
\text { land } \\
\text { (ramang/ } \\
\text { kanguma) }\end{array}$ & $\begin{array}{l}\text { Shrub } \\
\text { (jamu) }\end{array}$ & $\begin{array}{l}\text { Land on a } \\
\text { river bank } \\
\text { (mondu) }\end{array}$ & $\begin{array}{l}\text { Homegarden } \\
\text { (woka uma) }\end{array}$ & Ricefield \\
\hline Kabo'ta & $\begin{array}{l}\text { Elephant foot yam, } \\
\text { Suweg }\end{array}$ & $\begin{array}{l}\text { Amorphophallus } \\
\text { campanulatus }\end{array}$ & Alternative food & & $\cdot$ & & - & • & & & \\
\hline lowa katta & $\begin{array}{l}\text { Zaminkand, } \\
\text { Porang, Iles-iles }\end{array}$ & $\begin{array}{l}\text { Amorphophallus } \\
\text { oncophillus }\end{array}$ & $\begin{array}{l}\text { Animal feed (market } \\
\text { potential) }\end{array}$ & & $\cdot$ & & - & - & & & \\
\hline Manila & Peanut & Arachis hypogaea & & - & - & & & & - & - & \\
\hline Walawi & Pigeon pea & Cajanus cajan & Food and market & & & & & & & & \\
\hline Komangge & Job's tears & Coix lacryma-jobi L & Supplementary food & - & & & & & - & - & \\
\hline $\begin{array}{l}\text { Luwa hareu apeu, } \\
\text { Luwa mandu, Luwa } \\
\text { kambu, Luwa kamelarara, } \\
\text { Luwa engal }\end{array}$ & $\begin{array}{l}\text { Yam } \\
\text { Coconut yam } \\
\text { Sweet potato }\end{array}$ & Dioscorea alata & Alternative food & - & - & & & - & & - & \\
\hline Lutang & $\begin{array}{l}\text { Lesser yam } \\
\text { Gembili }\end{array}$ & Dioscorea esculenta & Alternative food & - & - & & & • & & • & \\
\hline Iwi & $\begin{array}{l}\text { Bitter yam } \\
\text { Gadung }\end{array}$ & $\begin{array}{l}\text { Dioscorea hispida } \\
\text { Dennst }\end{array}$ & Alternative food & & & • & & - & & & \\
\hline Katapu & White yam & Ipomoe batatas & Alternative food & - & $\cdot$ & & & - & & - & \\
\hline Katapu merah & Red yam & Ipomoe batatas & Alternative food & - & - & & & • & & - & \\
\hline Luwaye & Cassava & Manihot esculenta & Alternative food & - & - & & & - & & - & \\
\hline Padi & Rice & Oryza sativa & Staple food & & - & & & & $\cdot$ & & - \\
\hline Kani & Foxtail millet & Setaria italica & Supplementary food & - & & & & & - & - & \\
\hline Watar hamu & Sorghum & Sorghum bicolor L & Staple food (some) & - & - & & & & - & - & \\
\hline Kamborung & Maize & Zea mays & Staple food & - & - & & & & - & - & \\
\hline
\end{tabular}


Perennial plants

\begin{tabular}{|c|c|c|c|c|c|c|c|c|c|c|}
\hline Local name & Popular & Latin & $\begin{array}{l}\text { Farm } \\
\text { land in } \\
\text { valley } \\
\text { (woka } \\
\text { lola) }\end{array}$ & $\begin{array}{l}\text { Forest } \\
\text { (utang) }\end{array}$ & $\begin{array}{l}\text { Farm } \\
\text { land in } \\
\text { highland } \\
\text { (woka } \\
\text { palindi) }\end{array}$ & $\begin{array}{l}\text { Savanna } \\
\text { (maradda) }\end{array}$ & $\begin{array}{l}\text { Shrub } \\
\text { (jamu) }\end{array}$ & $\begin{array}{l}\text { Homegarden } \\
\text { (woka uma) }\end{array}$ & $\begin{array}{l}\text { Fallow } \\
\text { (ramang } \\
\text { /kanguma) }\end{array}$ & $\begin{array}{l}\text { Spring } \\
\text { (mata } \\
\text { wai) }\end{array}$ \\
\hline Yepohambaku & Aisuli & Acacia oraria & & & • & - & - & & - & \\
\hline Karing ah & & Acacia sp & & & - & - & - & & - & \\
\hline $\begin{array}{l}\text { Billa } \\
\text { Bakuwa }\end{array}$ & $\begin{array}{l}\text { Bael fruit, Maja } \\
\text { Mojo }\end{array}$ & Aegle marmelos & & & - & & - & & - & \\
\hline Mangasu apu/Wangga Tupi & & Albizia procera & & & • & • & • & & - & \\
\hline Ritta & & Alstonia scholaris & & - & - & - & - & & - & \\
\hline Halai & & Alstonia spectabilis & & - & - & - & - & & - & \\
\hline Wangga Kollu & & Alyxia buxifolia & & - & - & & - & & & - \\
\hline Mente & Cashew & Anacardium occidentale & & & & & & - & & \\
\hline Anona & $\begin{array}{l}\text { Custard apple } \\
\text { Srikaya }\end{array}$ & Annona squamosal & & & • & & & - & & \\
\hline Pinang & Betel nut & Areca catechu & & & - & & & - & - & \\
\hline Sukun & Breadfruit & Artocarpus altilis & & & • & & & • & & \\
\hline Nangka & Jackfruit & Artocarpus heterophyllus & & & • & & & • & & \\
\hline Talicu & & Barringtonia sp & & & • & & - & & - & - \\
\hline Lontar & & Borassus flabellifer & - & & • & & & - & - & \\
\hline Kamalu Pau & Mangga hutan & Buchania arborescens & & - & • & & - & & • & - \\
\hline Kalliandra & & Calliandra calothyrsus & - & & • & & • & - & - & \\
\hline Dora & Nyamplung & Calophyllum inophyllum Linn & & & - & & - & & & - \\
\hline Sakura Sumba & $\begin{array}{l}\text { Apple blossom tree } \\
\text { Johar }\end{array}$ & Cassia javanica & & & • & - & & - & - & \\
\hline Kokur & Coconut & Cocos nucifera & - & & - & & & & & \\
\hline Kananggar & & Dillenia sp & & & • & - & - & & - & \\
\hline Wudi & $\begin{array}{l}\text { Indian coral tree } \\
\text { Dadap }\end{array}$ & Erythrina variegate & & & • & & & & - & • \\
\hline Unknown & & Exocarpus & & - & - & & & & - & - \\
\hline Wangga & & Ficus sp & & - & • & & • & & - & • \\
\hline Gamal & & Gliricidia sepium & & & - & - & & - & - & \\
\hline Jaluk & & Glochidion littorale & & & - & & - & & - & \\
\hline
\end{tabular}




\begin{tabular}{|c|c|c|c|c|c|c|c|c|c|c|}
\hline Local name & Popular & Latin & $\begin{array}{l}\text { Farm } \\
\text { land in } \\
\text { valley } \\
\text { (woka } \\
\text { lola) }\end{array}$ & $\begin{array}{l}\text { Forest } \\
\text { (utang) }\end{array}$ & $\begin{array}{l}\text { Farm } \\
\text { land in } \\
\text { highland } \\
\text { (woka } \\
\text { palindi) }\end{array}$ & $\begin{array}{l}\text { Savanna } \\
\text { (maradda) }\end{array}$ & $\begin{array}{l}\text { Shrub } \\
\text { (jamu) }\end{array}$ & $\begin{array}{l}\text { Homegarden } \\
\text { (woka uma) }\end{array}$ & $\begin{array}{l}\text { Fallow } \\
\text { (ramang } \\
\text { /kanguma) }\end{array}$ & $\begin{array}{l}\text { Spring } \\
\text { (mata } \\
\text { wai) }\end{array}$ \\
\hline Jati putih & Gmelina & Gmelina arborea & & & - & & & - & & \\
\hline Kapaluh & & Grewira acuminate & & & - & & - & & - & \\
\hline Unknown & $\begin{array}{l}\text { Coastal cottonwood, } \\
\text { Waru }\end{array}$ & Hibiscus teleaceaus & & & - & & - & - & - & \\
\hline Kehi/Kedondong pagar & Indian ash tree & Lannea coromandelica & - & & - & & & - & - & \\
\hline Lamtoro & White leadtree & Leucaena leucocephala & - & & - & & - & - & - & \\
\hline Ndinu Bara atau Ndinu Putih & & Macaranga tanarius & & - & - & & - & - & - & \\
\hline Nara & $\begin{array}{l}\text { Red Kamala } \\
\text { Kamala }\end{array}$ & Mallotus phillipensis & & - & & & - & & & \\
\hline Kapilut & & Planchonella obovate & & - & - & & • & & • & \\
\hline Injuwatu & & Pleiogynium timoriense & & - & & & - & & & - \\
\hline Kawilu & & Premna japonica & & & - & & • & & • & \\
\hline $\begin{array}{l}\text { Rokarunggut/Ramul } \\
\text { Ai Kenawa (Sumba) }\end{array}$ & $\begin{array}{l}\text { Red sandalwood } \\
\text { Angsana }\end{array}$ & Ptereocarpus indicus & & - & - & & • & & • & \\
\hline Kapapa Kalta & & Rhincosia minima & & & - & & - & & - & \\
\hline Cendana & & Santalum album & & & • & & & • & & \\
\hline Nuru (Injung hutan) & $\begin{array}{l}\text { Soapberry tree } \\
\text { Kedondong hutan }\end{array}$ & Sapindus saponaria & & - & • & & - & & - & \\
\hline Jamba & $\begin{array}{l}\text { Ceylon oak } \\
\text { Kesambi }\end{array}$ & Scheilechera oleosa & & • & • & • & • & & - & \\
\hline Johar & Cassia tree & Senna siamea & & & - & - & - & • & - & \\
\hline Gala-gala & Turi & Sesbania grandiflora Pers & - & & - & & & - & - & \\
\hline Bakau & & Sonneratia spp & & & & & & & & \\
\hline Kedondong & & Spondias dulcis & & & - & & & - & - & \\
\hline Kalumbang/Kelumpang & Kepuh Java/ Kayu nias & Sterculia foetida & & - & - & & - & & - & - \\
\hline Mahoni & Mahogany & Swietenia mahagony & - & & - & • & & • & - & - \\
\hline Lobung & Salam (Bayleaf) & Syzygium polyanthum & - & - & - & & - & & - & - \\
\hline Asam & & Tamarindus indica & & & • & - & & • & & \\
\hline Jati & Teakwood & Tectona grandis & & & - & & & - & - & \\
\hline Cimung/nggai & & Timonius Timon & & • & • & - & • & & • & - \\
\hline Kaparak & & Trema sp & & - & - & - & - & & - & - \\
\hline Andalinga & & Unknown & & • & & & • & & & . \\
\hline
\end{tabular}




\begin{tabular}{|c|c|c|c|c|c|c|c|c|c|c|}
\hline Local name & Popular & Latin & $\begin{array}{l}\text { Farm } \\
\text { land in } \\
\text { valley } \\
\text { (woka } \\
\text { lola) }\end{array}$ & $\begin{array}{l}\text { Forest } \\
\text { (utang) }\end{array}$ & $\begin{array}{l}\text { Farm } \\
\text { land in } \\
\text { highland } \\
\text { (woka } \\
\text { palindi) }\end{array}$ & $\begin{array}{l}\text { Savanna } \\
\text { (maradda) }\end{array}$ & $\begin{array}{l}\text { Shrub } \\
\text { (jamu) }\end{array}$ & $\begin{array}{l}\text { Homegarden } \\
\text { (woka uma) }\end{array}$ & $\begin{array}{l}\text { Fallow } \\
\text { (ramang } \\
\text { /kanguma) }\end{array}$ & $\begin{array}{l}\text { Spring } \\
\text { (mata } \\
\text { wai) }\end{array}$ \\
\hline Hambolu & & Unknown & & & & - & - & - & & - \\
\hline Hayeyu & & Unknown & & & & - & - & - & & - \\
\hline Kalituahu & & Unknown & & & - & - & - & - & - & \\
\hline Kambu & & Unknown & & & - & - & - & & - & \\
\hline Kanjilu & & Unknown & & & & - & - & - & & - \\
\hline Karunggut & & Unknown & & - & - & & - & & & - \\
\hline Katang & & Unknown & & - & - & & - & & & - \\
\hline Kayu Pappa & & Unknown & & - & - & & - & - & & - \\
\hline Lehu & & Unknown & & - & - & & - & - & & - \\
\hline Lenduwacu & & Unknown & & - & - & & - & - & & - \\
\hline Lolu & & Unknown & & - & - & & - & & & - \\
\hline Lumbundaba & & Unknown & & - & - & & - & & & - \\
\hline Mandiduau & & Unknown & & $\cdot$ & - & & - & & & - \\
\hline Rikawudu & & Unknown & & - & - & - & & & - & \\
\hline Tai bahu & & Unknown & & $\cdot$ & & & & & & - \\
\hline Tai manginung & & Unknown & & - & & & & & & - \\
\hline Tangarang & & Unknown & & & & - & & - & & - \\
\hline Kom & $\begin{array}{l}\text { Appeldam } \\
\text { Bidara }\end{array}$ & Ziziphus mauritiana & & • & - & - & & - & - & \\
\hline
\end{tabular}


Grass, shrubs and herbs

\begin{tabular}{|c|c|c|c|}
\hline Local name & Others & Latin & Livestock feed \\
\hline Illah & & Andropogon sp & - \\
\hline Pahomba & & Andropogon sp & - \\
\hline Katewul & & Andropogon sp & - \\
\hline Kandaung (lewa) & & Axonopus & - \\
\hline Pahomba & & Chloris barbata & • \\
\hline Tailonga atau Tai Belalang & & Chromolaena odorata & - \\
\hline Ndaica & & Cynodon dactilon & - \\
\hline Kamel manila & & Desmodium heterophyllum & - \\
\hline Kanda Wung & & Digitaria sanguinalis (Harig vingergras) & - \\
\hline Mbatakambaku atau Patalutut atau Hondkarambo & & Eleusina indica & - \\
\hline Kamelanara atau Reha & & Fimbristyllis & • \\
\hline Kateoul & & Heteropogon tricitus & • \\
\hline Wora & True indigo, Tarum & Indigofera tinctoria & \\
\hline Unknown & & Ischaenum timorense & \\
\hline Mangata & & Paspalum conjugatum & - \\
\hline Rumba jawa & King grass & Pennisetum purpureum & - \\
\hline Kepapang & & Phaseolus lunatus & \\
\hline Sirih/piper & & Piper betle & \\
\hline Kambaung atau Kandaung & & Pogonatherum crinitum & - \\
\hline Bunga Kapapang & & Rynchosiu & \\
\hline Murukapuka or Moru kapuka & & Sorghum nitidum & - \\
\hline Kamelawata (Lewa), Rapu (Haharu) & & Sorghum propinquum & - \\
\hline Pahomba & & Sorgum halepansa & - \\
\hline
\end{tabular}





\section{WORKING PAPERS WITH DOIs}

2005

1. Agroforestry in the drylands of eastern Africa: a call to action

2. Biodiversity conservation through agroforestry: managing tree species diversity within a network of community-based, nongovernmental, governmental and research organizations in western Kenya.

3. Invasion of prosopis juliflora and local livelihoods: Case study from the Lake Baringo area of Kenya

4. Leadership for change in farmers organizations: Training report: Ridar Hotel, Kampala, 29th March to 2nd April 2005.

5. Domestication des espèces agroforestières au Sahel : situation actuelle et perspectives

6. Relevé des données de biodiversité ligneuse: Manuel du projet biodiversité des parcs agroforestiers au Sahel

7. Improved land management in the Lake Victoria Basin: TransVic Project's draft report.

8. Livelihood capital, strategies and outcomes in the Taita hills of Kenya

9. Les espèces ligneuses et leurs usages: Les préférences des paysans dans le Cercle de Ségou, au Mali

10. La biodiversité des espèces ligneuses: Diversité arborée et unités de gestion du terroir dans le Cercle de Ségou, au Mali

2006

11. Bird diversity and land use on the slopes of Mt. Kilimanjaro and the adjacent plains, Tanzania

12. Water, women and local social organization in the Western Kenya Highlands

13. Highlights of ongoing research of the World Agroforestry Centre in Indonesia

14. Prospects of adoption of tree-based systems in a rural landscape and its likely impacts on carbon stocks and farmers' welfare: The FALLOW Model Application in Muara Sungkai, Lampung, Sumatra, in a 'Clean Development Mechanism' context

15. Equipping integrated natural resource managers for healthy Agroforestry landscapes.

17. Agro-biodiversity and CGIAR tree and forest science: approaches and examples from Sumatra.

18. Improving land management in eastern and southern Africa: A review of policies.

19. Farm and household economic study of Kecamatan Nanggung, Kabupaten Bogor, Indonesia: A socio-economic base line study of Agroforestry innovations and livelihood enhancement.

20. Lessons from eastern Africa's unsustainable charcoal business.

21. Evolution of RELMA's approaches to land management: Lessons from two decades of research and development in eastern and southern Africa

22. Participatory watershed management: Lessons from RELMA's work with farmers in eastern Africa.

23. Strengthening farmers' organizations: The experience of RELMA and ULAMP.

24. Promoting rainwater harvesting in eastern and southern Africa.

25. The role of livestock in integrated land management.

26. Status of carbon sequestration projects in Africa: Potential benefits and challenges to scaling up. 
27. Social and Environmental Trade-Offs in Tree Species Selection: A Methodology for Identifying Niche Incompatibilities in Agroforestry [Appears as AHI Working Paper no. 9]

28. Managing tradeoffs in agroforestry: From conflict to collaboration in natural resource management. [Appears as AHI Working Paper no. 10]

29. Essai d'analyse de la prise en compte des systemes agroforestiers pa les legislations forestieres au Sahel: Cas du Burkina Faso, du Mali, du Niger et du Senegal.

30. Etat de la recherche agroforestière au Rwanda etude bibliographique, période 1987-2003

2007

31. Science and technological innovations for improving soil fertility and management in Africa: A report for NEPAD's Science and Technology Forum.

32. Compensation and rewards for environmental services.

33. Latin American regional workshop report compensation.

34. Asia regional workshop on compensation ecosystem services.

35. Report of African regional workshop on compensation ecosystem services.

36. Exploring the inter-linkages among and between compensation and rewards for ecosystem services CRES and human well-being

37. Criteria and indicators for environmental service compensation and reward mechanisms: realistic, voluntary, conditional and pro-poor

38. The conditions for effective mechanisms of compensation and rewards for environmental services.

39. Organization and governance for fostering Pro-Poor Compensation for Environmental Services.

40. How important are different types of compensation and reward mechanisms shaping poverty and ecosystem services across Africa, Asia \& Latin America over the Next two decades?

41. Risk mitigation in contract farming: The case of poultry, cotton, woodfuel and cereals in East Africa.

42. The RELMA savings and credit experiences: Sowing the seed of sustainability

43. Yatich J., Policy and institutional context for NRM in Kenya: Challenges and opportunities for Landcare.

44. Nina-Nina Adoung Nasional di So! Field test of rapid land tenure assessment (RATA) in the Batang Toru Watershed, North Sumatera.

45. Is Hutan Tanaman Rakyat a new paradigm in community based tree planting in Indonesia?

46. Socio-Economic aspects of brackish water aquaculture (Tambak) production in Nanggroe Aceh Darrusalam.

47. Farmer livelihoods in the humid forest and moist savannah zones of Cameroon.

48. Domestication, genre et vulnérabilité : Participation des femmes, des Jeunes et des catégories les plus pauvres à la domestication des arbres agroforestiers au Cameroun.

49. Land tenure and management in the districts around Mt Elgon: An assessment presented to the Mt Elgon ecosystem conservation programme.

50. The production and marketing of leaf meal from fodder shrubs in Tanga, Tanzania: A pro-poor enterprise for improving livestock productivity.

51. Buyers Perspective on Environmental Services (ES) and Commoditization as an approach to liberate ES markets in the Philippines. 
52. Towards Towards community-driven conservation in southwest China: Reconciling state and local perceptions.

53. Biofuels in China: An Analysis of the Opportunities and Challenges of Jatropha curcas in Southwest China.

54. Jatropha curcas biodiesel production in Kenya: Economics and potential value chain development for smallholder farmers

55. Livelihoods and Forest Resources in Aceh and Nias for a Sustainable Forest Resource Management and Economic Progress

56. Agroforestry on the interface of Orangutan Conservation and Sustainable Livelihoods in Batang Toru, North Sumatra.

2008

57. Assessing Hydrological Situation of Kapuas Hulu Basin, Kapuas Hulu Regency, West Kalimantan.

58. Assessing the Hydrological Situation of Talau Watershed, Belu Regency, East Nusa Tenggara.

59. Kajian Kondisi Hidrologis DAS Talau, Kabupaten Belu, Nusa Tenggara Timur.

60. Kajian Kondisi Hidrologis DAS Kapuas Hulu, Kabupaten Kapuas Hulu, Kalimantan Barat.

61. Lessons learned from community capacity building activities to support agroforest as sustainable economic alternatives in Batang Toru orang utan habitat conservation program (Martini, Endri et al.)

62. Mainstreaming Climate Change in the Philippines.

63. A Conjoint Analysis of Farmer Preferences for Community Forestry Contracts in the Sumber Jaya Watershed, Indonesia.

64. The highlands: a shared water tower in a changing climate and changing Asia

65. Eco-Certification: Can It Deliver Conservation and Development in the Tropics.

66. Designing ecological and biodiversity sampling strategies. Towards mainstreaming climate change in grassland management.

67. Towards mainstreaming climate change in grassland management policies and practices on the Tibetan Plateau

68. An Assessment of the Potential for Carbon Finance in Rangelands

69 ECA Trade-offs Among Ecosystem Services in the Lake Victoria Basin.

69. The last remnants of mega biodiversity in West Java and Banten: an in-depth exploration of RaTA (Rapid Land Tenure Assessment) in Mount Halimun-Salak National Park Indonesia

70. Le business plan d'une petite entreprise rurale de production et de commercialisation des plants des arbres locaux. Cas de quatre pépinières rurales au Cameroun.

71. Les unités de transformation des produits forestiers non ligneux alimentaires au Cameroun. Diagnostic technique et stratégie de développement Honoré Tabuna et Ingratia Kayitavu.

72. Les exportateurs camerounais de safou (Dacryodes edulis) sur le marché sous régional et international. Profil, fonctionnement et stratégies de développement.

73. Impact of the Southeast Asian Network for Agroforestry Education (SEANAFE) on agroforestry education capacity.

74. Setting landscape conservation targets and promoting them through compatible land use in the Philippines.

75. Review of methods for researching multistrata systems. 
76. Study on economical viability of Jatropha curcas L. plantations in Northern Tanzania assessing farmers' prospects via cost-benefit analysis

77. Cooperation in Agroforestry between Ministry of Forestry of Indonesia and International Center for Research in Agroforestry

78. "China's bioenergy future. an analysis through the Lens if Yunnan Province

79. Land tenure and agricultural productivity in Africa: A comparative analysis of the economics literature and recent policy strategies and reforms

80. Boundary organizations, objects and agents: linking knowledge with action in Agroforestry watersheds

81. Reducing emissions from deforestation and forest degradation (REDD) in Indonesia: options and challenges for fair and efficient payment distribution mechanisms

2009

82. Mainstreaming climate change into agricultural education: challenges and perspectives

83. Challenging conventional mindsets and disconnects in conservation: the emerging role of ecoagriculture in Kenya's landscape mosaics

84. Lesson learned RATA garut dan bengkunat: suatu upaya membedah kebijakan pelepasan kawasan hutan dan redistribusi tanah bekas kawasan hutan

85. The emergence of forest land redistribution in Indonesia

86. Commercial opportunities for fruit in Malawi

87. Status of fruit production processing and marketing in Malawi

88. Fraud in tree science

89. Trees on farm: analysis of global extent and geographical patterns of agroforestry

90. The springs of Nyando: water, social organization and livelihoods in Western Kenya

91. Building capacity toward region-wide curriculum and teaching materials development in agroforestry education in Southeast Asia

92. Overview of biomass energy technology in rural Yunnan (Chinese - English abstract)

93. A pro-growth pathway for reducing net GHG emissions in China

94. Analysis of local livelihoods from past to present in the central Kalimantan Ex-Mega Rice Project area

95. Constraints and options to enhancing production of high quality feeds in dairy production in Kenya, Uganda and Rwanda

2010

96. Agroforestry education in the Philippines: status report from the Southeast Asian Network for Agroforestry Education (SEANAFE)

97. Economic viability of Jatropha curcas L. plantations in Northern Tanzania- assessing farmers' prospects via cost-benefit analysis.

98. Hot spot of emission and confusion: land tenure insecurity, contested policies and competing claims in the central Kalimantan Ex-Mega Rice Project area

99. Agroforestry competences and human resources needs in the Philippines

100. CES/COS/CIS paradigms for compensation and rewards to enhance environmental Services 
101. Case study approach to region-wide curriculum and teaching materials development in agroforestry education in Southeast Asia

102. Stewardship agreement to reduce emissions from deforestation and degradation (REDD): Lubuk Beringin's Hutan Desa as the first village forest in Indonesia

103. Landscape dynamics over time and space from ecological perspective

104. Komoditisasi atau koinvestasi jasa lingkungan: skema imbal jasa lingkungan program peduli sungai di DAS Way Besai, Lampung, Indonesia

105. Improving smallholders' rubber quality in Lubuk Beringin, Bungo district, Jambi province, Indonesia: an initial analysis of the financial and social benefits

106. Rapid Carbon Stock Appraisal (RACSA) in Kalahan, Nueva Vizcaya, Philippines

107. Tree domestication by ICRAF and partners in the Peruvian Amazon: lessons learned and future prospects in the domain of the Amazon Initiative eco-regional program

108. Memorias del Taller Nacional: "Iniciativas para Reducir la Deforestación en la region Andino Amazónica", 09 de Abril del 2010. Proyecto REALU Peru

109. Percepciones sobre la Equidad y Eficiencia en la cadena de valor de REDD en Perú -Reporte de Talleres en Ucayali, San Martín y Loreto, 2009. Proyecto REALU-Perú.

110. Reducción de emisiones de todos los Usos del Suelo. Reporte del Proyecto REALU Perú Fase 1

111. Programa Alternativas a la Tumba-y-Quema (ASB) en el Perú. Informe Resumen y Síntesis de la Fase II. 2da. versión revisada

112. Estudio de las cadenas de abastecimiento de germoplasma forestal en la amazonía Boliviana

113. Biodiesel in the Amazon

114. Estudio de mercado de semillas forestales en la amazonía Colombiana

115. Estudio de las cadenas de abastecimiento de germoplasma forestal en Ecuador http://dx.doi.org10.5716/WP10340.PDF

116. How can systems thinking, social capital and social network analysis help programs achieve impact at scale?

117. Energy policies, forests and local communities in the Ucayali Region, Peruvian Amazon

118. NTFPs as a Source of Livelihood Diversification for Local Communities in the Batang Toru Orangutan Conservation Program

119. Studi Biodiversitas: Apakah agroforestry mampu mengkonservasi keanekaragaman hayati di DAS Konto?

120. Estimasi Karbon Tersimpan di Lahan-lahan Pertanian di DAS Konto, Jawa Timur

121. Implementasi Kaji Cepat Hidrologi (RHA) di Hulu DAS Brantas, Jawa Timur. http://dx.doi.org/10.5716/WP10338.PDF

122. Kaji Cepat Hidrologi di Daerah Aliran Sungai Krueng Peusangan, NAD,Sumatra http://dx.doi.org/10.5716/WP10337.PDF

123. A Study of Rapid Hydrological Appraisal in the Krueng Peusangan Watershed, NAD, Sumatra. http://dx.doi.org/10.5716/WP10339.PDF

2011

124. An Assessment of farm timber value chains in Mt Kenya area, Kenya

125. A Comparative financial analysis of current land use systems and implications for the adoption of improved agroforestry in the East Usambaras, Tanzania

126. Agricultural monitoring and evaluation systems 
127. Challenges and opportunities for collaborative landscape governance in the East Usambara Mountains, Tanzania

128. Transforming Knowledge to Enhance Integrated Natural Resource Management Research, Development and Advocacy in the Highlands of Eastern Africa http://dx.doi.org/10.5716/WP11084.PDF

129. Carbon-forestry projects in the Philippines: potential and challenges The Mt Kitanglad Range forest-carbon development http://dx.doi.org10.5716/WP11054.PDF

130. Carbon forestry projects in the Philippines: potential and challenges. The Arakan Forest Corridor forest-carbon project. http://dx.doi.org10.5716/WP11055.PDF

131. Carbon-forestry projects in the Philippines: potential and challenges. The Laguna Lake Development Authority's forest-carbon development project. http://dx.doi.org/10.5716/WP11056.PDF

132. Carbon-forestry projects in the Philippines: potential and challenges. The Quirino forest-carbon development project in Sierra Madre Biodiversity Corridor http://dx.doi.org10.5716/WP11057.PDF

133. Carbon-forestry projects in the Philippines: potential and challenges. The Ikalahan Ancestral Domain forest-carbon development http://dx.doi.org10.5716/WP11058.PDF

134. The Importance of Local Traditional Institutions in the Management of Natural Resources in the Highlands of Eastern Africa. http://dx.doi.org/10.5716/WP11085.PDF

135. Socio-economic assessment of irrigation pilot projects in Rwanda. http://dx.doi.org/10.5716/WP11086.PDF

136. Performance of three rambutan varieties (Nephelium lappaceum L.) on various nursery media. http://dx.doi.org/10.5716/WP11232.PDF

137. Climate change adaptation and social protection in agroforestry systems: enhancing adaptive capacity and minimizing risk of drought in Zambia and Honduras http://dx.doi.org/10.5716/WP11269.PDF

138. Does value chain development contribute to rural poverty reduction? Evidence of asset building by smallholder coffee producers in Nicaragua http://dx.doi.org/10.5716/WP11271.PDF

139. Potential for biofuel feedstock in Kenya. http://dx.doi.org/10.5716/WP11272.PDF

140. Impact of fertilizer trees on maize production and food security in six districts of Malawi. http://dx.doi.org/10.5716/WP11281.PDF

2012

141. Fortalecimiento de capacidades para la gestión del Santuario Nacional Pampa Hermosa: Construyendo las bases para un manejo adaptativo para el desarrollo local. Memorias del Proyecto. http://dx.doi.org/10.5716/WP12005.PDF

142. Understanding rural institutional strengthening: A cross-level policy and institutional framework for sustainable development in Kenya http://dx.doi.org/10.5716/WP12012.PDF

143. Climate change vulnerability of agroforestry http://dx.doi.org/10.5716/WP16722.PDF

144. Rapid assesment of the inner Niger delta of Mali http://dx.doi.org/10.5716/WP12021.PDF

145. Designing an incentive program to reduce on-farm deforestationin the East Usambara Mountains, Tanzania http://dx.doi.org/10.5716/WP12048.PDF

146. Extent of adoption of conservation agriculture and agroforestry in Africa: the case of Tanzania, Kenya, Ghana, and Zambia http://dx.doi.org/10.5716/WP12049.PDF 
147. Policy incentives for scaling up conservation agriculture with trees in Africa: the case of Tanzania, Kenya, Ghana and Zambia http://dx.doi.org/10.5716/WP12050.PDF

148. Commoditized or co-invested environmental services? Rewards for environmental services scheme: River Care program Way Besai watershed, Lampung, Indonesia. http://dx.doi.org/10.5716/WP12051.PDF

149. Assessment of the headwaters of the Blue Nile in Ethiopia. http://dx.doi.org/10.5716/WP12160.PDF

150. Assessment of the uThukela Watershed, Kwazaulu. http://dx.doi.org/10.5716/WP12161.PDF

151. Assessment of the Oum Zessar Watershed of Tunisia. http://dx.doi.org/10.5716/WP12162.PDF

152. Assessment of the Ruwenzori Mountains in Uganda. http://dx.doi.org/10.5716/WP12163.PDF

153. History of agroforestry research and development in Viet Nam. Analysis of research opportunities and gaps. http://dx.doi.org/10.5716/WP12052.PDF

154. REDD+ in Indonesia: a Historical Perspective. http://dx.doi.org/10.5716/WP12053.PDF

155. Agroforestry and Forestry in Sulawesi series: Livelihood strategies and land use system dynamics in South Sulawesi http://dx.doi.org/10.5716/WP12054.PDF

156. Agroforestry and Forestry in Sulawesi series: Livelihood strategies and land use system dynamics in Southeast Sulawesi. http://dx.doi.org/10.5716/WP12055.PDF

157. Agroforestry and Forestry in Sulawesi series: Profitability and land-use systems in South and Southeast Sulawesi. http://dx.doi.org/10.5716/WP12056.PDF

158. Agroforestry and Forestry in Sulawesi series: Gender, livelihoods and land in South and Southeast Sulawesi http://dx.doi.org/10.5716/WP12057.PDF

159. Agroforestry and Forestry in Sulawesi series: Agroforestry extension needs at the community level in AgFor project sites in South and Southeast Sulawesi, Indonesia. http://dx.doi.org/10.5716/WP12058.PDF

160. Agroforestry and Forestry in Sulawesi series: Rapid market appraisal of agricultural, plantation and forestry commodities in South and Southeast Sulawesi. http://dx.doi.org/10.5716/WP12059.PDF

2013

161. Diagnosis of farming systems in the Agroforestry for Livelihoods of Smallholder farmers in Northwestern Viet Nam project http://dx.doi.org/10.5716/WP13033.PDF

162. Ecosystem vulnerability to climate change: a literature review. http://dx.doi.org/10.5716/WP13034.PDF

163. Local capacity for implementing payments for environmental services schemes: lessons from the RUPES project in northeastern Viet Nam http://dx.doi.org/10.5716/WP13046.PDF

164. Seri Agroforestri dan Kehutanan di Sulawesi: Agroforestry dan Kehutanan di Sulawesi: Strategi mata pencaharian dan dinamika sistem penggunaan lahan di Sulawesi Selatan http://dx.doi.org/10.5716/WP13040.PDF

165. Seri Agroforestri dan Kehutanan di Sulawesi: Mata pencaharian dan dinamika sistem penggunaan lahan di Sulawesi Tenggara http://dx.doi.org/10.5716/WP13041.PDF

166. Seri Agroforestri dan Kehutanan di Sulawesi: Profitabilitas sistem penggunaan lahan di Sulawesi Selatan dan Sulawesi Tenggara http://dx.doi.org/10.5716/WP13042.PDF

167. Seri Agroforestri dan Kehutanan di Sulawesi: Gender, mata pencarian dan lahan di Sulawesi Selatan dan Sulawesi Tenggara http://dx.doi.org/10.5716/WP13043.PDF 
168. Seri Agroforestri dan Kehutanan di Sulawesi: Kebutuhan penyuluhan agroforestri pada tingkat masyarakat di lokasi proyek AgFor di Sulawesi Selatan dan Tenggara, Indonesia. http://dx.doi.org/10.5716/WP13044.PDF

169. Seri Agroforestri dan Kehutanan di Sulawesi: Laporan hasil penilaian cepat untuk komoditas pertanian, perkebunan dan kehutanan di Sulawesi Selatan dan Tenggara http://dx.doi.org/10.5716/WP13045.PDF

170. Agroforestry, food and nutritional security http://dx.doi.org/10.5716/WP13054.PDF

171. Stakeholder Preferences over Rewards for Ecosystem Services: Implications for a REDD+ Benefit Distribution System in Viet Nam http://dx.doi.org/10.5716/WP13057.PDF

172. Payments for ecosystem services schemes: project-level insights on benefits for ecosystems and the rural poor http://dx.doi.org/10.5716/WP13001.PDF

173. Good practices for smallholder teak plantations: keys to success http://dx.doi.org/10.5716/WP13246.PDF

174. Market analysis of selected agroforestry products in the Vision for Change Project intervention Zone, Côte d'Ivoire http://dx.doi.org/10.5716/WP13249.PDF

175. Rattan futures in Katingan: why do smallholders abandon or keep their gardens in Indonesia's 'rattan district'? http://dx.doi.org/10.5716/WP13251.PDF

176. Management along a gradient: the case of Southeast Sulawesi's cacao production landscapes http://dx.doi.org/10.5716/WP13265.PDF

2014

177. Are trees buffering ecosystems and livelihoods in agricultural landscapes of the Lower Mekong Basin? Consequences for climate-change adaptation. http://dx.doi.org/10.5716/WP14047.PDF

178. Agroforestry, livestock, fodder production and climate change adaptation and mitigation in East Africa: issues and options. http://dx.doi.org/10.5716/WP14050.PDF

179. Trees on farms: an update and reanalysis of agroforestry's global extent and socio-ecological characteristics. http://dx.doi.org/10.5716/WP14064.PDF

180. Beyond reforestation: an assessment of Vietnam's REDD+ readiness. http://dx.doi.org/10.5716/WP14097.PDF

181. Farmer-to-farmer extension in Kenya: the perspectives of organizations using the approach. http://dx.doi.org/10.5716/WP14380.PDF

182. Farmer-to-farmer extension in Cameroon: a survey of extension organizations. http://dx.doi.org/10.5716/WP14383.PDF

183. Farmer-to-farmer extension approach in Malawi: a survey of organizations: a survey of organizations http://dx.doi.org/10.5716/WP14391.PDF

184. Seri Agroforestri dan Kehutanan di Sulawesi: Kuantifikasi jasa lingkungan air dan karbon pola agroforestri pada hutan rakyat di wilayah sungai Jeneberang

185. Options for Climate-Smart Agriculture at Kaptumo Site in Kenyahttp://dx.doi.org/10.5716/WP14394.PDF

2015

186. Agroforestry for Landscape Restoration and Livelihood Development in Central Asia http://dx.doi.org/10.5716/WP14143.PDF 
187. "Projected Climate Change and Impact on Bioclimatic Conditions in the Central and SouthCentral Asia Region" http://dx.doi.org/10.5716/WP14144.PDF

188. Land Cover Changes, Forest Loss and Degradation in Kutai Barat, Indonesia. http://dx.doi.org/10.5716/WP14145.PDF

189. The Farmer-to-Farmer Extension Approach in Malawi: A Survey of Lead Farmers. http://dx.doi.org/10.5716/WP14152.PDF

190. Evaluating indicators of land degradation and targeting agroforestry interventions in smallholder farming systems in Ethiopia. http://dx.doi.org/10.5716/WP14252.PDF

191. Land health surveillance for identifying land constraints and targeting land management options in smallholder farming systems in Western Cameroon

192. Land health surveillance in four agroecologies in Malawi

193. Cocoa Land Health Surveillance: an evidence-based approach to sustainable management of cocoa landscapes in the Nawa region, South-West Côte d'Ivoire http://dx.doi.org/10.5716/WP14255.PDF

194. Situational analysis report: Xishuangbanna autonomous Dai Prefecture, Yunnan Province, China. http://dx.doi.org/10.5716/WP14255.PDF

195. Farmer-to-farmer extension: a survey of lead farmers in Cameroon. http://dx.doi.org/10.5716/WP15009.PDF

196. From transition fuel to viable energy source Improving sustainability in the sub-Saharan charcoal sector http://dx.doi.org/10.5716/WP15011.PDF

197. Mobilizing Hybrid Knowledge for More Effective Water Governance in the Asian Highlands http://dx.doi.org/10.5716/WP15012.PDF

198. Water Governance in the Asian Highlands http://dx.doi.org/10.5716/WP15013.PDF

199. Assessing the Effectiveness of the Volunteer Farmer Trainer Approach in Dissemination of Livestock Feed Technologies in Kenya vis-à-vis other Information Sources http://dx.doi.org/10.5716/WP15022.PDF

200. The rooted pedon in a dynamic multifunctional landscape: Soil science at the World Agroforestry Centre http://dx.doi.org/10.5716/WP15023.PDF

201. Characterising agro-ecological zones with local knowledge. Case study: Huong Khe district, $\mathrm{Ha}$ Tinh, Viet Nam http://dx.doi.org/10.5716/WP15050.PDF

202. Looking back to look ahead: Insight into the effectiveness and efficiency of selected advisory approaches in the dissemination of agricultural technologies indicative of Conservation Agriculture with Trees in Machakos County, Kenya. http://dx.doi.org/10.5716/WP15065.PDF

203. Pro-poor Biocarbon Projects in Eastern Africa Economic and Institutional Lessons. http://dx.doi.org/10.5716/WP15022.PDF

204. Projected climate change impacts on climatic suitability and geographical distribution of banana and coffee plantations in Nepal. http://dx.doi.org/10.5716/WP15294.PDF

205. Agroforestry and Forestry in Sulawesi series: Smallholders' coffee production and marketing in Indonesia. A case study of two villages in South Sulawesi Province. http://dx.doi.org/10.5716/WP15690.PDF

206. Mobile phone ownership and use of short message service by farmer trainers: a case study of Olkalou and Kaptumo in Kenya http://dx.doi.org/10.5716/WP15691.PDF

207. Associating multivariate climatic descriptors with cereal yields: a case study of Southern Burkina Faso http://dx.doi.org/10.5716/WP15273.PDF

208. Preferences and adoption of livestock feed practices among farmers in dairy management groups in Kenya http://dx.doi.org/10.5716/WP15675.PDF 
209. Scaling up climate-smart agriculture: lessons learned from South Asia and pathways for success http://dx.doi.org/10.5716/WP15720.PDF

210. Agroforestry and Forestry in Sulawesi series: Local perceptions of forest ecosystem services and collaborative formulation of reward mechanisms in South and Southeast Sulawesi http://dx.doi.org/10.5716/WP15721.PDF

211. Potential and challenges in implementing the co-investment of ecosystem services scheme in Buol District, Indonesia. http://dx.doi.org/10.5716/WP15722.PDF

212. Tree diversity and its utilization by the local community in Buol District, Indonesia http://dx.doi.org/10.5716/WP15723.PDF

213 Vulnerability of smallholder farmers and their preferences on farming practices in Buol District, Indonesia http://dx.doi.org/10.5716/WP15724.PDF

214. Dynamics of Land Use/Cover Change and Carbon Emission in Buol District, Indonesia http://dx.doi.org/10.5716/WP15725.PDF

215. Gender perspective in smallholder farming practices in Lantapan, Phillippines. http://dx.doi.org/10.5716/WP15726.PDF

216. Vulnerability of smallholder farmers in Lantapan, Bukidnon. http://dx.doi.org/10.5716/WP15727.PDF

217. Vulnerability and adaptive capacity of smallholder farmers in Ho Ho Sub-watershed, Ha Tinh Province, Vietnam http://dx.doi.org/10.5716/WP15728.PDF

218. Local Knowledge on the role of trees to enhance livelihoods and ecosystem services in northern central Vietnam http://dx.doi.org/10.5716/WP15729.PDF

219. Land-use/cover change in Ho Ho Sub-watershed, Ha Tinh Province, Vietnam. http://dx.doi.org/10.5716/WP15730.PDF

2016

220. Agroforestry and Forestry in Sulawesi series: Evaluation of the Agroforestry Farmer Field Schools on agroforestry management in South and Southeast Sulawesi, Indonesia. http://dx.doi.org/10.5716/WP16002.PDF

221. Farmer-to-farmer extension of livestock feed technologies in Rwanda: A survey of volunteer farmer trainers and organizations. http://dx.doi.org/10.5716/WP16005.PDF

222. Projected Climate Change Impact on Hydrology, Bioclimatic Conditions, and Terrestrial Ecosystems in the Asian Highlands http://dx.doi.org/10.5716/WP16006.PDF

223. Adoption of Agroforestry and its impact on household food security among farmers in Malawi http://dx.doi.org/10.5716/WP16013.PDF

224. Agroforestry and Forestry in Sulawesi series: Information channels for disseminating innovative agroforestry practices to villages in Southern Sulawesi, Indonesia http://dx.doi.org/10.5716/WP16034.PDF

225. Agroforestry and Forestry in Sulawesi series: Unravelling rural migration networks.Landtenure arrangements among Bugis migrant communities in Southeast Sulawesi. http://dx.doi.org/10.5716/WP16035.PDF

226. Agroforestry and Forestry in Sulawesi series: Women's participation in agroforestry: more benefit or burden? A gendered analysis of Gorontalo Province. http://dx.doi.org/10.5716/WP16036.PDF

227. Kajian Kelayakan dan Pengembangan Desain Teknis Rehabilitasi Pesisir di Sulawesi Tengah. http://dx.doi.org/10.5716/WP16037.PDF

228. Selection of son tra clones in North West Vietnam. http://dx.doi.org/10.5716/WP16038.PDF 
229. Growth and fruit yield of seedlings, cuttings and grafts from selected son tra trees in Northwest Vietnam http://dx.doi.org/10.5716/WP16046.PDF

230. Gender-Focused Analysis of Poverty and Vulnerability in Yunnan, China http://dx.doi.org/10.5716/WP16071.PDF

231. Seri Agroforestri dan Kehutanan di Sulawesi: Kebutuhan Penyuluhan Agroforestri untuk Rehabilitasi Lahan di Sumba Timur, Nusa Tenggara Timur, Indonesia. http://dx.doi.org/10.5716/WP16077.PDF

232. Agroforestry and Forestry in Sulawesi series: Agroforestry extension needs for land rehabilitation in East Sumba, East Nusa Tenggara, Indonesia. http://dx.doi.org/10.5716/WP16078.PDF

233. Central hypotheses for the third agroforestry paradigm within a common definition. http://dx.doi.org/10.5716/WP16079.PDF

234. Assessing smallholder farmers' interest in shade coffee trees: The Farming Systems of Smallholder Coffee Producers in the Gisenyi Area, Rwanda: a participatory diagnostic study. http://dx.doi.org/10.5716/WP16104.PDF

235. Review of agricultural market information systems in |sub-Saharan Africa. http://dx.doi.org/10.5716/WP16110.PDF

236. Vision and road map for establishment of a protected area in Lag Badana, Lower Jubba, Somalia. http://dx.doi.org/10.5716/WP16127.PDF

237. Replicable tools and frameworks for Bio-Carbon Development in West Africa. http://dx.doi.org/10.5716/WP16138.PDF

238. Existing Conditions, Challenges and Needs in the Implementation of Forestry and Agroforestry Extension in Indonesia. http://dx.doi.org/10.5716/WP16141.PDF

239. Situasi Terkini, Tantangan dan Kebutuhan Pelaksanaan Penyuluhan Kehutanan dan Agroforestri di Indonesia. http://dx.doi.org/10.5716/WP16142.PDF

240. The national agroforestry policy of India: experiential learning in development and delivery phases. http://dx.doi.org/10.5716/WP16143.PDF

241. Agroforestry and Forestry in Sulawesi series: Livelihood strategies and land-use system dynamics in Gorontalo. http://dx.doi.org/10.5716/WP16157.PDF

242. Seri Agroforestri dan Kehutanan di Sulawesi: Strategi mata pencaharian dan dinamika sistem penggunaan lahan di Gorontalo. http://dx.doi.org/10.5716/WP16158.PDF

243. Ruang, Gender dan Kualitas Hidup Manusia: Sebuah studi Gender pada komunitas perantau dan pengelola kebun di Jawa Barat. http://dx.doi.org/10.5716/WP16159.PDF

244. Gendered Knowledge and perception in managing grassland areas in East Sumba, Indonesia. http://dx.doi.org/10.5716/WP16160.PDF

245. Pengetahuan dan persepsi masyarakat pengelola padang aavana, Sebuah Kajian Gender di Sumba Timur. http://dx.doi.org/10.5716/WP16161.PDF

246. Dinamika Pengambilan Keputusan pada komunitas perantau dan pengelola kebun di Jawa Barat. http://dx.doi.org/10.5716/WP16162.PDF

247. Gaharu (eaglewood) domestication: Biotechnology, markets and agroforestry options. http://dx.doi.org/10.5716/WP16163.PDF

248. Marine habitats of the Lamu-Kiunga coast: an assessment of biodiversity value, threats and opportunities. http://dx.doi.org/10.5716/WP16167.PDF

249. Assessment of the biodiversity in terrestrial landscapes of the Witu protected area and surroundings, Lamu County Kenya. http://dx.doi.org/10.5716/WP16172.PDF

250. An ecosystem services perspective on benefits that people derive from biodiversity of Coastal forests in Lamu County, Kenya http://dx.doi.org/10.5716/WP16173.PDF 
251. Assessment of the biodiversity in terrestrial and marine landscapes of the proposed Laga Badana National Park and surrounding areas, Jubaland, Somalia.

http://dx.doi.org/10.5716/WP16174.PDF

2017

252. Preferensi Petani terhadap Topik Penyuluhan dan Penyebaran Informasi Agroforestri di Indonesia. http://dx.doi.org/10.5716/WP16181.PDF

253. Seri Agroforestri dan Kehutanan di Sulawesi: Keanekaragaman hayati jenis pohon pada hutan rakyat agroforestri di DAS Balangtieng, Sulawesi Selatan. http://dx.doi.org/10.5716/WP16182.PDF

254. Potensi dan Tantangan dalam Pengembangan Skema Ko-Investasi Jasa Lingkungan di Kabupaten Buol, Indonesia. http://dx.doi.org/10.5716/WP17008.PDF

255. Keragaman Jenis Pohon dan Pemanfaatannya oleh Masyarakat di Kabupaten Buol, Indonesia. http://dx.doi.org/10.5716/WP17009.PDF

256. Kerentanan dan preferensi sistem pertanian petani di Kabupaten Buol, Indonesia. http://dx.doi.org/10.5716/WP17010.PDF

257. Dinamika Perubahan Penggunaan/Tutupan Lahan Serta Cadangan Karbon di Kabupaten Buol, Indonesia. http://dx.doi.org/10.5716/WP17011.PDF

258. The Effectiveness of the Volunteer Farmer Trainer Approach vis-à-vis Other Information Sources in Dissemination of Livestock Feed Technologies in Uganda.

http://dx.doi.org/10.5716/WP17104.PDF

259. Agroforestry and Forestry in Sulawesi series: Impact of agricultural-extension booklets on community livelihoods in South and Southeast Sulawesi. http://dx.doi.org/10.5716/WP17125.PDF

260. Petani Menjadi Penyuluh, Mungkinkah? Sebuah Pendekatan Penyuluhan dari Petani ke Petani di Kabupaten Sumba Timur. http://dx.doi.org/10.5716/WP17145.PDF

261. Dampak Perubahan Tutupan Lahan terhadap Kondisi Hidrologi di Das Buol, Kabupaten Buol, Sulawesi Tengah: Simulasi dengan Model Genriver. http://dx.doi.org/10.5716/WP17146.PDF

262. Analisis Tapak Mata Air Umbulan, Pasuruan, Jawa Timur. Kajian elemen biofisik dan persepsi masyarakat. http://dx.doi.org/10.5716/WP17147.PDF

263. Planned comparisons demystified. http://dx.doi.org/10.5716/WP17354.PDF

264. Soil health decision support for NERC digital soil platforms: A survey report. http://dx.doi.org/10.5716/WP17355.PDF

265. Seri Pembangunan Ekonomi Pedesaan Indonesia: Menanam di bukit gundul: Pengetahuan masyarakat lokal dalam upaya restorasi lahan di Sumba

Timur. http://dx.doi.org/10.5716/WP17356.PDF

266. Tree diversity and carbon stock in three districts of Kutai Timur, Pasir and Berau, East Kalimantan http://dx.doi.org/10.5716/WP17357.PDF

267. Tree Diversity and Carbon Stock in Various Land Use Systems of Banyuasin and Musi Banyuasin Districts, South Sumatera http://dx.doi.org/10.5716/WP17358.PDF

268. Tree diversity and carbon stock in various land cover systems of Jayapura, Jayawijaya and Merauke Districts, Papua Province http://dx.doi.org/10.5716/WP17359.PDF

269. Modelling tree production based on farmers' knowledge: case for kapok (Ceiba pentandra) and candlenut (Aleurites mollucana) under various agroforestry scenarios.

http://dx.doi.org/10.5716/WP17361.PDF 
270. The Impact of Land Cover and Climate Change on Present and Future Watershed Condition. Study case: Tugasan, Alanib and Kulasihan Sub-watershed of Manupali Watershed, Lantapan, Bukidnon, Philippines. http://dx.doi.org/10.5716/WP17362.PDF

271. Tree Diversity and Above-ground Carbon Stock estimation in Various Land use Systems in Banjarnegara, Banyumas and Purbalingga, Central Java. http://dx.doi.org/10.5716/WP17363.PDF

272. Agroforestry and Forestry in Sulawesi series: Landscape Management Strategies in Sulawesi: Review of Intervention Options. http://dx.doi.org/10.5716/WP17364.PDF

273. Household Food-Security and Nutritional Status of Women and Children in Buol Regency, Central Sulawesi, Indonesia. http://dx.doi.org/10.5716/WP17365.PDF

274. Palm oil expansion in tropical forest margins or sustainability of production? Focal issues of regulations and private standards. http://dx.doi.org/10.5716/WP17366.PDF

2018

275. Decision analysis methods guide: agricultural policy for nutrition http://dx.doi.org/10.5716/WP18001.PDF

276. Supporting human nutrition in Africa through the integration of new and orphan crops into food systems: Placing the work of the African Orphan Crops Consortium in context. http://dx.doi.org/10.5716/WP18003.PDF

277. Seri Pembangunan Ekonomi Pedesaan Indonesia. Pilihan Manajemen Budidaya Kacang Tanah sebagai Upaya untuk Memperbaiki Penghidupan Masyarakat Haharu. http://dx.doi.org/10.5716/WP18004.PDF

278. Estudio de línea de base CCAFS a nivel de hogar en Nicaragua y Costa Rica. Fase de diagnóstico del estudio: "Contribución de la diversidad arbórea a los medios de vida para la adaptación y la mitigación al cambio climático. http://dx.doi.org/10.5716/WP18005.PDF

279. Understanding tree cover transition, drivers and stakeholder perspectives for effective landscape governance. A case study in Na Nhan commune, Dien Bien province, Vietnam. http://dx.doi.org/10.5716/WP18006.PDF

280. El Sistema "Quesungual": Agroforestería y manejo de suelos para la producción de maíz y frijol en laderas. http://dx.doi.org/10.5716/WP18007.PDF

281. Probabilistic Decision Modelling to Determine Impacts on Natural Resource Management and Livelihood Resilience in Marsabit County, Kenya. http://dx.doi.org/10.5716/WP18008.PDF

282. Shifting discourse, shifting power: how is climate change mitigation and justice negotiated in Indonesia? http://dx.doi.org/10.5716/WP18009.PDF

283. Result of Land Use Planning and Land Administration (LULA) Implementation in South Sumatra, East Kalimantan, Central Java and Papua. http://dx.doi.org/10.5716/WP18010.PDF

284. Farmers' preferences for training topics and dissemination of agroforestry information in Indonesia. http://dx.doi.org/10.5716/WP18015.PDF

285. CSA-Diagnostic (CSA-Dx): A primer for investigating the 'climate-smartness' of ag technologies. http://dx.doi.org/10.5716/WP18020.PDF

286. An analysis of the vulnerability of poor communities in Yunnan Province, China. http://dx.doi.org/10.5716/WP18021.PDF

287. Gendered space and quality of life: gender study of out-migration and smallholding agroforestry communities in West Java Province, Indonesia. http://dx.doi.org/10.5716/WP18024.PDF 
288 Evaluation of UTZ certification coffee businesses in Guatemala, Honduras and Nicaragua. http://dx.doi.org/10.5716/WP18028.PDF

289 Agroforestry species of Peru: annotated list and contribution to prioritization for genetic conservation. http://dx.doi.org/10.5716/WP18029.PDF 

The World Agroforestry Centre is an autonomous, non-profit research organization whose vision is a rural transformation in the developing world as smallholder households increase their use of trees in agricultural landscapes to improve food security, nutrition, income, health, shelter, social cohesion, energy resources and environmental sustainability. The Centre generates science-based knowledge about the diverse roles that trees play in agricultural landscapes, and uses its research to advance policies and practices, and their implementation that benefit the poor and the environment. It aims to ensure that all this is achieved by enhancing the quality of its science work, increasing operational efficiency, building and maintaining strong partnerships, accelerating the use and impact of its research, and promoting greater cohesion, interdependence and alignment within the organization.

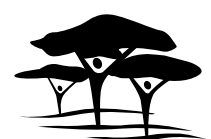

United Nations Avenue, Gigiri • PO Box 30677 • Nairobi, $00100 \cdot$ Kenya Telephone: +254 207224000 or via USA +1 6508336645 Fax: +254207224001 or via USA +1 6508336646

Email: worldagroforestry@cgiar.org•www.worldagroforestry.org

Southeast Asia Regional Program • Sindang Barang • Bogor 16680

PO Box $161 \cdot$ Bogor $16001 \cdot$ Indonesia

Telephone: +62 2518625415 • Fax: +62 2518625416

- Email: icraf-indonesia@cgiar.org

www.worldagroforestry.org/region/southeast-asia

blog.worldagroforestry.org 